\title{
Mumps Outbreaks in Vaccinated Populations - Is It Time to Re-assess the Clinical Efficacy of Vaccines?
}

\author{
Anna R. Connell ${ }^{1 *}$, Jeff Connell ${ }^{2}$, T. Ronan Leahy ${ }^{3,4}$ and Jaythoon Hassan ${ }^{1,2}$ \\ ${ }^{1}$ National Children's Research Centre, Children's Health Ireland, Dublin, Ireland, ${ }^{2}$ National Virus Reference Laboratory, \\ University College Dublin, Dublin, Ireland, ${ }^{3}$ Children's Health Ireland, Dublin, Ireland, ${ }^{4}$ Department of Pediatrics, University of \\ Dublin, Trinity College, Dublin, Ireland
}

\section{OPEN ACCESS}

Edited by:

Jose Luis Subiza,

Inmunotek SL, Spain

Reviewed by:

Thorsten Demberg

Marker Therapeutics, United States

Richard Kennedy,

Mayo Clinic, United States

${ }^{*}$ Correspondence:

Anna R. Connell

anna.connel/@ucd.ie

Specialty section:

This article was submitted to Vaccines and Molecular Therapeutics,

a section of the journal

Frontiers in Immunology

Received: 20 March 2020

Accepted: 31 July 2020

Published: 18 September 2020

Citation:

Connell AR, Connell J, Leahy TR and Hassan J (2020) Mumps Outbreaks in Vaccinated Populations - Is It Time to

Re-assess the Clinical Efficacy of Vaccines? Front. Immunol. 11:2089.

doi: 10.3389/fimmu.2020.02089
History illustrates the remarkable public health impact of mass vaccination, by dramatically improving life expectancy and reducing the burden of infectious diseases and co-morbidities worldwide. It has been perceived that if an individual adhered to the MMR vaccine schedule that immunity to mumps virus (MuV) would be lifelong. Recent mumps outbreaks in individuals who had received two doses of the Measles Mumps Rubella (MMR) vaccine has challenged the efficacy of the MMR vaccine. However, clinical symptoms, complications, viral shedding and transmission associated with mumps infection has been shown to be reduced in vaccinated individuals, demonstrating a benefit of this vaccine. Therefore, the question of what constitutes a good mumps vaccine and how its impact is assessed in this modern era remains to be addressed. Epidemiology of the individuals most affected by the outbreaks (predominantly young adults) and variance in the circulating MuV genotype have been well-described alluding to a collection of influences such as vaccine hesitancy, heterogeneous vaccine uptake, primary, and/or secondary vaccine failures. This review aims to discuss in detail the interplay of factors thought to be contributing to the current mumps outbreaks seen in highly vaccinated populations. In addition, how mumps diagnoses has progressed and impacted the understanding of mumps infection since a mumps vaccine was first developed, the limitations of current laboratory tests in confirming protection in vaccinated individuals and how vaccine effectiveness is quantified are also considered. By highlighting knowledge gaps within this area, this state-of-the-art review proposes a change of perspective regarding the impact of a vaccine in a highly vaccinated population from a clinical, diagnostic and public perspective, highlighting a need for a paradigm shift on what is considered vaccine immunity.

\section{Keywords: mumps outbreaks, vaccinated populations, immunity, vaccine efficacy, protection}

\section{INTRODUCTION}

\section{Mumps Virus}

$\mathrm{MuV}$ is an enveloped, non-segmented, negative-sense, single stranded RNA virus that varies between a spherical and pleiomorphic shape of $\sim 200 \mathrm{~nm}(85-300 \mathrm{~nm})(1,2) . \mathrm{MuV}$ is responsible for an acute viral infection, spread by respiratory droplets (via coughs, sneezes) and urine $(3,4)$. With an incubation period of 14-25 days, MuV replicates in the nasopharynx and regional lymph nodes, with a secondary viremia occurring late in the incubation period $(5,6)$. MuV can be detected from saliva up to 7 days prior, and as late as 9 days after clinical onset of parotitis (7). 
The $\mathrm{MuV}$ genome of seven genes consists of 15,384 nucleotides, and encodes six structural proteins and at least two non-structural proteins; the nucleocapsid protein (NP), V protein $(\mathrm{V})$, phosphoprotein $(\mathrm{P})$, matrix $(\mathrm{M})$ protein, fusion (F) protein, small hydrophobic $(\mathrm{SH})$ protein, hemagglutininneuraminidase $(\mathrm{HN})$ protein, and large $(\mathrm{L})$ protein. The role of the I protein is not known $(1,6,8)$. The $\mathrm{SH}$ gene is the most variable region of the $\mathrm{MuV}$ genome; a $2-4 \%$ intravariation and $8-18 \%$ inter-variation has been documented (9). This gene is used in molecular phylogeny for genotyping and to identify transmission patterns in populations (6). Despite being serologically monotypic, $12 \mathrm{MuV}$ genotypes (A to $\mathrm{L}$ ) have been described to date ( $\mathrm{MuV}$ genotypes $\mathrm{E}$ and $\mathrm{M}$ are omitted, as the $\mathrm{MuV}$ previously assigned to these groups were later re-assigned) $(1,9,10)$. The geographic distributions of the $\mathrm{MuV}$ genotypes varies worldwide but can co-circulate and thus drive temporal shifts in their distribution. Genotype A was frequently isolated in Europe until the 1990's. Currently genotypes C, D, E, G, and $\mathrm{H}$ are prevalent in Europe and the United States of America (USA) whereas genotypes B, F and I are more common in Asian countries (Table 1) $(10,18,86,87)$.

\section{Development of the Mumps Vaccine}

Since 1946 numerous mumps vaccines have been developed worldwide, varying in efficacy and safety profiles but primarily consisting of an attenuated live $\mathrm{MuV}$ without an adjuvant (6, 87-89). Currently in Europe and for the majority of the G20 countries who have a mumps vaccine in their immunization schedule (Table 1), the mumps vaccine is included as part of the trivalent measles, mumps rubella (MMR) vaccine, and is primarily administered in two doses $(90,91)$.

The Jeryl Lynn (JL) vaccine, derived from the genotype A $\mathrm{MuV}$ strain was first developed in the USA and has been used extensively in the United Kingdom (UK), Ireland and USA since it was licensed in 1967 (92). Derived from a single clinical sample, and propagated in a chick embryo cell culture, two viral isolates (JL2 and JL5) are present, differing by $\sim 414$ nucleotides and 87 amino acid changes (93-95).

The RIT 4385 mumps vaccine, developed from the dominant viral component (JL5) in the JL vaccine strain appears to have comparative safety and efficacy (seroconversion) profiles to the JL vaccine strain $(87,96-98)$. However, since no controlled clinical trials of efficacy have been published to compare the two doses of the two vaccines, the clinical significance of this observation is not known.

Despite the integration of the MMR vaccine into childhood immunization programs, cyclical outbreaks [defined as two or more cases linked by place and time (96)] of $\mathrm{MuV}$ have been documented in several highly vaccinated populations such as Ireland and the United Kingdom (6, 97-103). Between August 2018-and January 2020, 3,736 mumps cases were notified in Ireland, primarily affecting individuals between the ages of 1524 years. Of the $32 \%$ of cases that stated vaccination status, $72 \%$ had received two doses of the MMR vaccine (104). An upsurge of mumps cases has also occurred in 47 states of the United States over the last 2 decades, primarily affecting people between 18 and 24 years in close contact/shared settings (105).
In Indiana, $76.9 \%$ of mumps cases (84.9\% of university affiliated and $52 \%$ of community cases) had documented evidence of MMR vaccination (106). This results in a significant resource burden for public health departments to control.

Several reviews, both observational and systematic have demonstrated the clinical benefit of a mumps vaccine $(107,108)$, the pathogenesis and genomic diversity of the $\operatorname{MuV}(10,107,108)$ and the epidemiology surrounding the outbreak $(1,10,82)$. It is not clear why these mumps outbreaks occur, although it has been alluded to be due to a number of interrelated factors, such as sub-optimal vaccine uptake $(1,109,110)$, primary or secondary vaccine failure or failure of the mumps vaccine to protect individuals from infection (vaccine efficacy) (107) (Figure 1).

\section{Vaccine Hesitancy: How Public Perception Predominates}

History depicts the remarkable public health impact of mass vaccination. Previously inevitable childhood diseases with potentially debilitating or deadly outcomes have seen their rates plummet worldwide or become successfully eradicated. Immunizations of vaccine preventable diseases are estimated to prevent $\sim 2-3$ million deaths per annum and increase life expectancy by $\sim 29$ years (111). More recently there has been a shift in the public and media perception of vaccines to their safety, which has facilitated outbreaks such as mumps (112). Organized opposition to vaccinations has a long history; public outcry and resistance following the introduction of the smallpox vaccine in the nineteenth century led to the introduction in England of the Vaccination Act of 1853 (113).

With one in eight children in the USA under the age of 2 currently thought to be unvaccinated due to parental choice, the WHO now considers vaccine hesitancy as one of the ten threats to global health in 2019 (114). Vaccine hesitancy, defined as a "delay in acceptance or refusal of vaccines despite availability of vaccination services" involves a multitude of social, political, cultural and emotional factors in highly vaccinated, western populations $(115,116)$. One of the main issues is the parental concerns regarding the perceived risk of a vaccine to their child (such as timing/schedules of vaccines, associated pain of administration, and potential adverse effects) vs. the disease morbidity and mortality associated with the vaccine preventable disease $(117,118)$. The retracted paper published in the Lancet in 1999 (56) and "anti-vaccination" opinions on social media have also contributed to the persistent and insistent misinformation (116), despite vast follow-up epidemiological studies showing no relationship between the MMR vaccine and autism, or differing cognitive development/intelligence (118120). However, the resultant reaction of the public led to the uptake of the first MMR vaccine falling sharply from 1999, with uptake falling to below $75 \%$ in 2002 (104, 121). The age demographic that are experiencing the most cases of mumps in Ireland during the current ongoing outbreak would have been scheduled to have received the first MMR vaccine between 1997 and 2003. Nevertheless, no deductions can be made, due to the lack of vaccination status information provided with reported cases (104). 
TABLE 1 | Comparison of vaccine strain, schedule, and coverage in contrast to the circulating mumps strain and reported cases/year within G20 countries who currently utilize mumps containing vaccines as part of the national vaccination schedule.

\begin{tabular}{|c|c|c|c|c|c|c|}
\hline Country & Vaccine introduced & Vaccines (strains) & Vaccination schedule & $\begin{array}{l}\text { Approximate vaccine } \\
\text { coverage (VC) }\end{array}$ & Circulating strains & Reported cases/Year \\
\hline Argentina & $1997(11,12)$ & $\begin{array}{l}\text { Present: } J L(A) \text { strain. During } \\
\text { outbreaks, JL/JL derived } \\
\text { vaccines preferred among } \\
\text { adolescents and adults } \\
(12,13)\end{array}$ & $\begin{array}{l}\text { MMR 1: } 12 \text { MThs } \\
\text { MMR 2: } 5-6 \text { years (catch up at } 11 \\
\text { years). } \\
\text { From December 2018, the government } \\
\text { pays for all vaccinations }(12,14-16)\end{array}$ & $\begin{array}{l}\text { 2013: MMR1: 94\%; MMR2: 82\% } \\
\text { 2014: MMR1: 95\%; MMR2: 96\% } \\
\text { 2015: MMR1: 89\%; MMR2: 87\% } \\
\text { 2016: MMR1: 90\%; MMR2: 88\% } \\
\text { 2017: MMR1: 90\%; MMR2: } \\
\text { 91\% (14) }\end{array}$ & $\begin{array}{l}\text { D (2005) (17) } \\
\text { K/94-98 (until 2013) (18) }\end{array}$ & $\begin{array}{l}\text { 3772: } 2013 \\
\text { 87: } 2014 \\
\text { 156: } 2015 \\
\text { 74: } 2016 \\
\text { 4396: } 2017 \\
\text { 771: } 2018(19)\end{array}$ \\
\hline Australia & $1982(20)$ & $\mathrm{JL}(\mathrm{A})(21)$ & $\begin{array}{l}\text { 1982: MuCV: } 12 \text { MThs } \\
\text { 1989: MMR 1: } 12 \text { MThs } \\
\text { 1996: MMR 2: for adolescents } \\
\text { 1998: MMR 1: } 12 \text { MThs; MMR 2: } 4 \\
\text { years. Catch-up between } 4 \text { and } 16 \\
\text { years. } \\
\text { 2013: MMR 1: } 12 \text { MThs. } \\
\text { MMR 2 (MMRV): } 18 \text { MThs }(20,22)\end{array}$ & $\begin{array}{l}\text { 1998: Proof of } \\
\text { immunization/exemption } \\
\text { required for welfare benefits. } \\
\text { 2016: Immunizations required for } \\
\text { Family Tax Benefit "No Jab, No } \\
\text { Play" } \\
\text { 2017: } 93 \% \text { at } 2 \text { years. }(22,23)\end{array}$ & $\begin{array}{l}\text { J/07-08 (until 2013) G (2015) } \\
(18,24)\end{array}$ & $\begin{array}{l}\text { 216: } 2013 \\
\text { 187: } 2014 \\
\text { 633: } 2015 \\
\text { 800: } 2016 \\
\text { 806: } 2017 \\
\text { 634: } 2018 \text { (19) }\end{array}$ \\
\hline Brazil & $1992(25)$ & $\begin{array}{l}\text { 1992: Urabe (B) (MMR } \\
\text { campaign) } \\
\text { 1997: Urabe (B) and } \\
\text { Leningrad-Zagreb (N) (MMR } \\
\text { campaign) } \\
\text { 2003: RIT } 4385 \text { (A) (25-29) }\end{array}$ & $\begin{array}{l}\text { 2013: MMR 1: } 12 \text { MThs; MMR 2: 4-6 } \\
\text { years. Booster 1: } 11-19 \text { years. Booster } \\
\text { 2: After } 20 \text { years. } \\
\text { 2016: MMR 1: } 12 \text { MThs; MMR 2: } 15 \\
\text { MThs. } \\
\text { Two additional boosters before } 20 \text { years, } \\
\text { OR a single dose if over } 20 \text { years. } \\
(25,26)\end{array}$ & $\begin{array}{l}\text { 2013: MMR1: 100\%; MMR2: } \\
\text { 69\% } \\
\text { 2014: MMR1: 100\%; MMR2: } \\
\text { 89\% } \\
\text { 2015: MMR1: 96\%; MMR2: 80\% } \\
\text { 2016: MMR1: 95\%; MMR2: 77\% } \\
\text { 2017: MMR1: } 97 \% \text {; MMR2: } 41 \% \\
\text { (14) }\end{array}$ & $\begin{array}{l}\text { K/07(CAN) and K (until 2013) } \\
(18,30)\end{array}$ & $\begin{array}{l}\text { 2014-2015: 82\% increase } \\
\text { in reported cases in São } \\
\text { Paulo (31) }\end{array}$ \\
\hline Canada & $\begin{array}{l}\text { 1969: MuCV } \\
\text { 1972: Trivalent MuCV }\end{array}$ & $\begin{array}{l}\text { Mid-1980's (Urabe Am9 } \\
\text { MuCV). Withdrawn late 1980's. } \\
\text { 1970's: JL (A). Two different } \\
\text { MuCVs are used } \\
\text { interchangeably (32) }\end{array}$ & $\begin{array}{l}\text { MMR or MMRV vaccine. } \\
\text { MMR 1: } 12-15 \text { MThs } \\
\text { MMR 2: } 18 \text { MThs. No later than around } \\
\text { school entry (33) }\end{array}$ & $\begin{array}{l}\text { VC of } 2 \text { doses of MuCV in } \\
\text { school-aged children has been } \\
90 \% \text { for the past } 10 \text { years. in } \\
\text { Toronto schools } \\
\text { VC 2017-2018: } \\
7 \text { years: } 87.4 \% \text {; } 17 \text { years; } \\
95 \% \text { (34) }\end{array}$ & $\begin{array}{l}\text { A/88, C/85, 88, 11-13 } \\
\text { Imported: D/07, 08, 09, 11; } \\
\text { F/11-12, G/05-13; H/07, 08, } \\
11-13 ; \mathrm{K} / 07,09,12-13 \text { (until } \\
2013 \text { ) } \\
\text { G (18, 33) }\end{array}$ & $\begin{array}{l}\text { 216: } 2013 \\
\text { 187: } 2014 \\
\text { 633: } 2015 \\
\text { 800: } 2016 \\
\text { 806: } 2017 \\
\text { 634: } 2018(19,35,36)\end{array}$ \\
\hline China & $\begin{array}{l}\text { 1990's: (voluntary) } \\
\text { 2008: (NIP) }\end{array}$ & $\begin{array}{l}\text { Since 1990: } \\
\text { Monovalent MuCV } \\
\text { Imported: MuCV JL(A) } \\
\text { Domestic: MuCV, mostly S79 } \\
\text { strain derived from JL(A) (37) }\end{array}$ & $\begin{array}{l}\text { Pre-2008: MuCV was voluntary and at } \\
\text { own expense. } \\
\text { 2008-present: MuCV introduced into } \\
\text { NIP. One dose of MuCV at 18-24 } \\
\text { MThs (38) }\end{array}$ & Not Available & $\begin{array}{l}\text { F/95, 01-12 (11-12/CAN); J/09 } \\
\text { (CHN-HK), G/09-11 (CHN-HK); } \\
\text { H/11(CHN-HK) (until 2013) (18) } \\
\text { 2013-2015: F (99\%), G (1\%) } \\
\text { (38); K (39) }\end{array}$ & $\begin{array}{l}\text { 327759: } 2013 \\
\text { 187500: } 2014 \\
\text { 182833: } 2015 \\
\text { 175001: } 2016 \\
\text { 252740: } 2017 \\
\text { 259071: } 2018(19)\end{array}$ \\
\hline France & 1983 & $\begin{array}{l}\text { 1983: Monovalent MuCV; } \\
\text { Urabe (B) 1986: MMR. Urabe } \\
\text { (B) 1992: MMR of Urabe (B) } \\
\text { discontinued } \\
\text { 1992-Present: JL (A) (40-42) }\end{array}$ & $\begin{array}{l}\text { 2005: VC documented at } 24 \text { MThs } \\
\text { MMR 1: 12 MThs. MMR 2: 16-18 MThs } \\
\text { (catch up 6-17 years) (43) }\end{array}$ & $\begin{array}{l}\text { 2009-2013: MMR 1: 90.4\%. } \\
\text { MMR 2: 78.2\% } \\
\text { MuCV compulsory for children } \\
\text { born from January } 12018 \\
(44,45)\end{array}$ & D/89; C/90 (until 2013) (18) & $\begin{array}{l}\text { 2: } 2015 \text { 6: } 2016 \text { 10: } 2017 \\
\text { 4: } 2018 \text { (19) }\end{array}$ \\
\hline
\end{tabular}




\begin{tabular}{|c|c|c|c|c|c|c|}
\hline Country & Vaccine introduced & Vaccines (strains) & Vaccination schedule & $\begin{array}{l}\text { Approximate vaccine } \\
\text { coverage (VC) }\end{array}$ & Circulating strains & Reported cases/Year \\
\hline Germany & $\begin{array}{l}\text { Former German } \\
\text { Democratic Republic: } \\
\text { No MuCV in NIP. } \\
\text { Former West Germany } \\
\text { (FWG): } \\
\text { 1976: }(10,46)\end{array}$ & $\begin{array}{l}\text { MuCV: } \\
\text { JL (A) } \\
\text { RIT4385 (A) } \\
\text { L-Zagreb (N) } \\
\text { [Reviewed in }(10,47)]\end{array}$ & $\begin{array}{l}\text { FWG: 1976: MuCV at } 12 \text { MThs } \\
\text { (voluntary); 1980: MuCV in NIP } \\
\text { 1991: } 2 \text { MMRs. Dose } 2 \text { at } \geqslant 5 \text { years } \\
\text { 1997: MMR 1: 11-14 MThs 1998: MMR } \\
\text { 2: 13 MThs-6 years 2001: MMR 1: } \\
\text { 11-14 MThs MMRV: 15-23 MThs. } \\
\text { Catch up doses: } 2-17 \text { years }(10,46)\end{array}$ & $\begin{array}{l}\text { 2009-2013: MMR 1: 97\%; } \\
\text { MMR 2 /MMRV: 93\%. } \\
(41,43,48,49)\end{array}$ & $\begin{array}{l}\text { A/87, 90; C/87, 90, 92, 93; D/77; } \\
\text { N/87; G/05, } 10 \text { (until 2013) (18) }\end{array}$ & $\begin{array}{l}\text { 837: } 2014 \\
\text { 699: } 2015 \\
\text { 741: } 2016 \\
\text { 652: } 2017 \\
\text { 534: } 2018(19)\end{array}$ \\
\hline Italy & 1980’s (50) & $\begin{array}{l}\text { Pre-2001: Urabe (B), Rubini (A) } \\
\text { (41) } \\
\text { 2001: JL (A), RIT4385 (A), } \\
\text { Urabe (B) (51) }\end{array}$ & $\begin{array}{l}\text { 1999: MMR offered free to all children in } \\
\text { the second year of life } \\
\text { 2005-2007: Two-dose schedule as part } \\
\text { of NIP } \\
\text { 2017: MMR mandatory for children born } \\
\text { from 2001. MMR 1: 13-15 MThs; MMR } \\
\text { 2: } 6 \text { years (52-54) }\end{array}$ & $\begin{array}{l}\text { 2013-2017: MMR 1: 88.6\%. } \\
\text { MMR 2: } 84.2 \% \\
\text { 2018: } 94.1 \%(55)\end{array}$ & Genotype G (56) & $\begin{array}{l}\text { 808: } 2013 \\
\text { 821: } 2014 \\
\text { 675: } 2015 \\
\text { 782: } 2016 \\
\text { 829: } 2017 \\
\text { 47: } 2018(57)\end{array}$ \\
\hline Mexico & $1998(58)$ & $\begin{array}{l}\text { Present: Triple Viral SRP } \\
\text { (sarampo, parotidite epidémica } \\
\text { e rubeola). JL (A) }\end{array}$ & $\begin{array}{l}\text { 1998: Two MuCV introduced } \\
\text { 2000: MuCV included to NIP } \\
\text { Present: MMR 1: } 12 \text { MThs; MMR 2: } 6 \\
\text { years (59). }\end{array}$ & $\begin{array}{l}\text { 2017: MMR1: 79\%; MMR2: } 62 \% \\
\text { 2016: MMR1: 97\%; MMR2: } 98 \% \\
\text { 2015: MMR1: } 100 \% \text {; } \\
\text { MMR2:96\% } \\
\text { 2014: MMR1: 98\%; MMR2: 96\% } \\
\text { 2013: MMR1: 89\%; MMR2: } 76 \% \\
(12,14,60)\end{array}$ & $H(2016)(59)$ & $\begin{array}{l}\text { 4142: } 2014 \\
\text { 3399: } 2015 \\
\text { 3646: } 2016 \\
(19,59,61)\end{array}$ \\
\hline $\begin{array}{l}\text { Russian } \\
\text { Federation }\end{array}$ & 1967 (62) & $\begin{array}{l}\text { MuCV used of Russian } \\
\text { production, in addition to } \\
\text { foreign combination vaccines. } \\
\text { Leningrad-3 (Genotype } \\
\text { unknown) commonly used } \\
(43,62)\end{array}$ & MMR 1: 12 MThs MMR 2: 6 years. (62) & $\begin{array}{l}\text { 2013-2017: } \\
\text { MMR 1 VC: 98\% } \\
\text { MMR 2 VC: 97\% } \\
\text { (63) }\end{array}$ & $\begin{array}{l}\text { N/53; C/94, 02-04; H/02-04 } \\
\text { (until 2013) (18) } \\
\mathrm{C} \text { and H (Novosibirsk) (64) }\end{array}$ & $\begin{array}{l}\text { 282: } 2013 \\
\text { 267: } 2014 \\
\text { 190: } 2015 \\
\text { 1106: } 2016 \\
\text { 4443: } 2017 \\
\text { 2027: } 2018(19)\end{array}$ \\
\hline Saudi Arabia & 1991 & $\begin{array}{l}\text { Urabe (B) } \\
J L(A)(41,65)\end{array}$ & $\begin{array}{l}\text { 1991: MMR 1: } 12 \text { MThs 1993: MMR } \\
\text { provided as a part of EPI. Required for } \\
\text { birth certificate 1998-2000: MMR } \\
\text { school campaign. 2002-present: a } \\
\text { 3-dose schedule Measles-containing } \\
\text { vaccine: Nine MThs MMR 1: } 12 \text { MThs; } \\
\text { MMR 2: 4-6 years. (66-69) }\end{array}$ & $\begin{array}{l}\text { 1998-2000 Campaign: 96.4\% } \\
\text { 2000: School Campaign } 96.6 \% \\
\text { 2006: 99\% of children received } \\
\text { MMR vaccine in Keddah. Delays } \\
\text { in vaccination have been } \\
\text { observed } \\
\text { 2014: MMR Campaign for } \\
\text { children in 1st grade (6/7 } \\
\text { years) (67-69) }\end{array}$ & Not Available & $\begin{array}{l}\text { 3: } 2015 \\
14: 2016 \\
47: 2017 \\
118: 2018(19)\end{array}$ \\
\hline South Korea & 1981 & $\begin{array}{l}\text { 1981-1997: Urabe AM9 (B) } \\
\text { 1997-2000: Rubini (A) } \\
\text { 2000-present: JL (A) }\end{array}$ & $\begin{array}{l}\text { 1980: MuCV introduced } \\
\text { 1985: MMR vaccine included in NIP } \\
\text { 1997: MMR 1: 12-15 MThs; MMR 2: } \\
\text { 4-6 years. } \\
\text { 2001: MMR mandatory for school } \\
\text { entrance (70) }\end{array}$ & $\begin{array}{l}\text { Two-dose MMR VC more than } \\
95 \% \text { among pre-school children } \\
\text { in Korea }(70) \text {. } \\
\text { Increase in mumps cases } \\
\text { attributed to Rubini strain }(71,72)\end{array}$ & $\begin{array}{l}\text { I/97-01; H/98-01, 07-10, } \\
\text { F/07-10 (until 2013) (18), } \\
\mathrm{H} \text { and I (71) }\end{array}$ & $\begin{array}{l}\text { 17022: } 2013 \\
\text { 1121: } 2017 \\
\text { 19237: } 2018(19)\end{array}$ \\
\hline
\end{tabular}


TABLE 1 | Continued

\begin{tabular}{|c|c|c|c|c|c|c|}
\hline Country & Vaccine introduced & Vaccines (strains) & Vaccination schedule & $\begin{array}{l}\text { Approximate vaccine } \\
\text { coverage (VC) }\end{array}$ & Circulating strains & Reported cases/Year \\
\hline Turkey & 1970's & $\begin{array}{l}\text { MMR (Kizamik Kizamikçik } \\
\text { Kabakulak (KKK): JL (A) } \\
(73,74)\end{array}$ & $\begin{array}{l}\text { 1970's-1987: As part of NIP. MMR dose } \\
\text { 1: Eight MThs; MMR 2: } 15 \text { MThs } \\
\text { 1987-1998: MMR 1: Nine MThs } \\
\text { 2006-present: MMR 1: 9-12 MThs } \\
\text { MMR 2: } 6 \text { years (compulsory, free) } \\
(73,74)\end{array}$ & $\begin{array}{l}\text { MMR used to eliminate Measles } \\
\text { and rubella. } \\
\text { 2013-2016: VC for MMR 1: } \\
\sim 97 \% \text { VC for MMR 2: } \\
\text { 90.5\% (75) }\end{array}$ & $\begin{array}{l}\text { Genotype H (2006-2007 winter } \\
\text { season) (76) } \\
\text { H/05-07 (until 2013) (18) }\end{array}$ & $\begin{array}{l}\text { 597: } 2013 \\
\text { 457: } 2014 \\
\text { 322: } 2015 \\
\text { 544: } 2016 \\
\text { 419: } 2017 \\
\text { 464: } 2018(19)\end{array}$ \\
\hline United Kingdom & $1988(77)$ & $\begin{array}{l}\text { 1988-1992: Urabe (B) } \\
\text { (withdrawn) 1992-1998: JL (A) } \\
\text { 1998-present: RIT-4385 (A) } \\
\text { (77). }\end{array}$ & $\begin{array}{l}\text { MMR 1: 12-13 MThs MMR 2: From } 40 \\
\text { MThs (78) }\end{array}$ & $\begin{array}{l}\text { 2013-2017: MMR 1: 92.6\%. } \\
\text { MMR 2: } 88.6 \% \text { (75, 79) } \\
\text { 2017-2018 (at 5 years): MuCV 1: } \\
\text { 94.9\%; MuCV 2: 87.2\% } \\
\text { 2019 (at } 5 \text { years): MuCV 1: } \\
\text { 94.5\%; MuCV 2: 86.4\% (80) }\end{array}$ & $\begin{array}{l}\text { B/89, 90; C/75, 80s, 90, 98-00, } \\
\text { 04, 06; D/96, 97, 99, 01-04; } \\
\text { F/99; G/96-13; H/88, 95-96, 98, } \\
\text { 00-04; K/99, 02; J/97, 03-06 } \\
\text { (until 2013) (18, 81) }\end{array}$ & $\begin{array}{l}\text { 4718: } 2013 \\
\text { 2958: } 2014 \\
\text { 1008: } 2015 \\
\text { 974: } 2016 \\
\text { 2360: } 2017 \\
\text { 1398: } 2018(19)\end{array}$ \\
\hline United States & 1967 & JL (A) (82) & $\begin{array}{l}\text { 1967: MuCV introduced } \\
\text { 1977: MuCV advised for > } 12 \text { MThs } \\
\text { 1989: Second MMR at 4-6 years. } \\
\text { Current MMR/MMRV: MMR 1: 12-15 } \\
\text { MThs MMR 2: 4-6 years. }(82,83)\end{array}$ & $\begin{array}{l}\text { 2013-2017: VC for } \geq 1 \text { dose } \\
\text { MMR: } ~ 91.9 \% \text {. (19-35 MThs) } \\
\text { 2017-2018: VC for two doses } \\
\text { MuCV 3 6/7 years: } \sim 94.3 \% \text {. } \\
\text { However, MuCV exemption } \\
\text { increased to 2.2\% } \\
(84,85)\end{array}$ & $\begin{array}{l}\text { A/45, 50, 63-91; C/08-10; D/09; } \\
\text { G/06-10; K/70s, 07, 08, 10; } \\
\text { H/88, 06-10 (up until 2013) (18) }\end{array}$ & $\begin{array}{l}\text { 584: } 2013 \\
\text { 1223: } 2014 \\
\text { 1308: } 2015 \\
\text { 6369: } 2016 \\
\text { 6109: } 2017(19)\end{array}$ \\
\hline
\end{tabular}

NIP, National immunization program; EPI, Extended Program of Immunization; VC, Vaccine Coverage; MuCV, mumps containing vaccine; MMR1, measles mumps rubella dose 1; MMR2, measles mumps rubella dose 2; JL, Jeryl Lynn (Genotype A) 


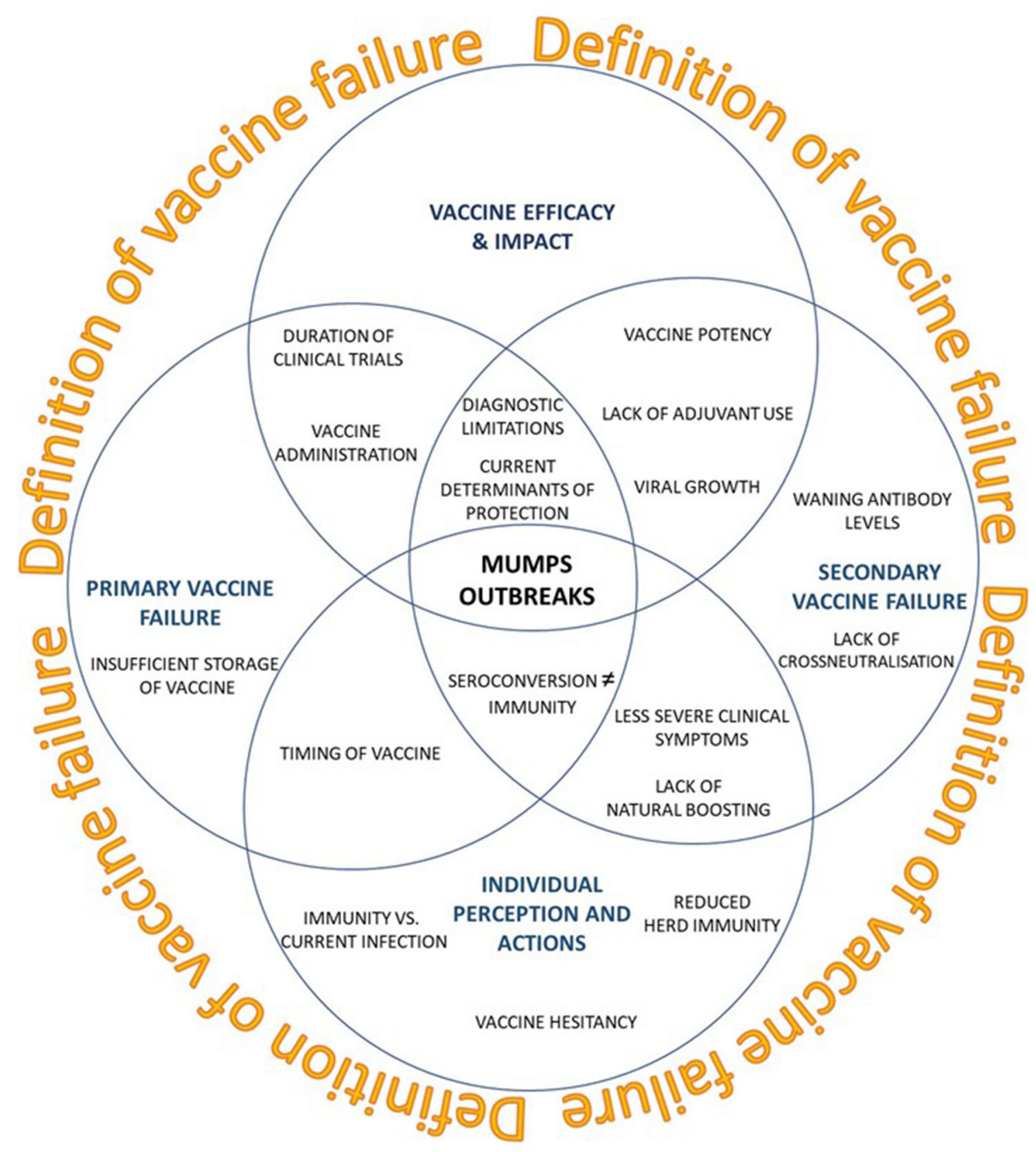

FIGURE 1 | Current perspectives on recent mumps outbreaks seen in vaccinated populations (blue circles). How impactful a vaccine is defined may lead to a paradigm shift in what constitutes an effective vaccine.

Heterogeneity of immunization coverage in specific populations or geographic locations of susceptibility is also becoming an important epidemiological issue in maintaining proficient population immunity for mumps $(3,109,122)$. The WHO recommends a $>95 \%$ MMR vaccine coverage for herd immunity. Maintenance of such coverage is well-demonstrated in Finland, where a country-wide 2-dose MMR vaccination program initiated in the 1980's eliminated measles, mumps and rubella within 25 years $(123,124)$. Recent publications from around the world indicate that the level of MMR vaccine uptake is far lower than what is recommended [reviewed in Ramanathan et al. (125)] (101, 126-129). Of the G20 nations that implement a mumps vaccine within their vaccination schedule, only 3 countries have maintained vaccine coverage levels of $>95 \%$ (Table 1). However, poor uptake/incomplete vaccination alone may not be the only issue relating to mumps outbreaks. In the 
Netherlands, mumps outbreaks still occurred with an overall herd immunity threshold of $86-92 \%$, and where 96 and $93 \%$ received the first and second MMR at 14 months and 9 years, respectively $(125,130)$.

\section{FACTORS FACILITATING CURRENT MUMPS OUTBREAKS IN HIGHLY VACCINATED POPULATIONS}

\section{The Changing Criteria of Mumps Diagnosis}

The clinical presentation of mumps is pathognomic (bi-lateral parotitis); therefore supporting laboratory diagnosis was rarely employed in the past. As the classical symptoms of mumps are not always typical, there may have been a significant number of individuals in the past who may have been infected but were not identified as such. When mumps vaccination was introduced in 1967, the criteria the vaccine had to meet was the proof that it was clinically effective, i.e., that it reduced the risk of disease in vaccinated individuals in real-world conditions over a set period. Such an example was seen the USA; the reported cases (i.e., diagnosis of clinical symptoms) of mumps declined from $>100$ cases per 100,000 population before 1967 (pre-vaccine era) to 10 cases per 100,000 population in 1977 , a reduction of $99 \%$ $(105,110,126,131)$. To note, clinical efficacy was probably based upon the reduction of the "classical bilateral presentation" rather than the milder mumps presentation. Therefore, one could argue that the original vaccine efficacy for clinical manifestations was over estimated.

Currently the laboratory diagnosis of mumps infection in Ireland is based upon two approaches: detection of mumps RNA by reverse transcriptase PCR (RT-PCR) in a buccal swab containing saliva, throat swab or urine specimen, and serological detection of immunoglobulin $\mathrm{M}$ (IgM) using a capture assay $(132,133)$. Both approaches for diagnosis are impacted significantly by the quality and timing of sample collection post-onset of symptoms and also if the subject is mumps naïve or had received mumps containing vaccine $(87,126,134,135)$.

There are challenges in using standard serological laboratory diagnostic methods to reliably confirm mumps re-infection of individuals who had been previously naturally infected or vaccinated $(130,136)$. Briefly, vaccinated individuals re-infected with $\mathrm{MuV}$ may only generate a weak or undetectable IgM response (133). Although a rise in IgG titer may also not occur in vaccinated individuals $(87,137)$, numerous studies have documented a rapid, variable increase in mumps-specific IgG levels, with neutralization antibody concentrations present up to 10 months post-infection $(130,138,139)$.

Therefore, Reverse Transcriptase-Polymerase Chain Reaction (RT-PCR) is recommended (133, 140), and was formally introduced in 2015 as the principle diagnostic tool in Ireland to detect mumps in oral fluids (141). RT-PCR can identify current mumps infection more effectively in vaccinated individuals than serological techniques alone as it identifies the presence of the $\mathrm{MuV}$ vs. the immunological response (IgG, $\operatorname{IgM}$ ), and has been previously shown to $100 \%$ correlate with viral culture results $(140,141)$.

The case numbers of more recent mumps outbreaks should always be assessed with this question in mind; are the number of mumps cases increasing, or/and are we better at diagnosing an acute infection? The latter seems to be the most probable, as many individuals who are being tested do not present with classical symptoms. In addition to enhanced surveillance of mumps cases, further optimizations of technologies are also occurring; the utilization of next-generation sequencing demonstrated that by editing one 2-fold degenerate nucleotide in the forward primer and three 2-fold degenerate nucleotides in the probe sequence optimized the fluorescence intensity and clinical sensitivity of the real-time RT-PCR when compared to the CDC-developed and WHO-recommended RT-PCR target [(NP) gene] leading to $\sim 11 \%$ increase in clinical sensitivity (i.e., Ct values that were $\sim 3.7$ cycles lower) (142).

\section{Are Primary and Secondary Vaccine Failures Implicated?}

Much is not known about the immunological response to the mumps vaccine strain. However, a number of young adults who were vaccinated as children over the last two decades have demonstrated an increased risk of $\mathrm{MuV}$ infection with time, which is assumed to be related to a decline of antibodies to sub-protective levels of immunity $(40,101,125,128,143-146)$.

\section{Primary Vaccine Failure}

Primary vaccine failure is defined as the lack of a sufficient initial antibody response to a vaccine in a recipient resulting in a lack of protective immune responses $(6,147)$. Although this type of vaccine failure may be because of improper storage/handling or administration of the vaccine, impacting its efficacy, it may also be due to the initial immunological response of an individual to the vaccine, which is usually quantified by the presence of antibodies that should be detectable in the weeks following vaccination. Primary vaccine failure was attributed to primaryschool outbreaks of both mumps and measles in Ireland, which subsequently resulted in reducing the age for the second dose of MMR2 vaccine from 10-14 years in 1999 to $4-5$ years of age (6). With the cyclical outbreaks occurring, it has been proposed that primary vaccine failure could again be a factor.

How is a response to a vaccine determined? In pre-licensure studies of the JL and Urabe mumps vaccines, high seroconversion and low failure rates were observed in children after the first vaccine dose (>90 and $5.5 \%$, respectively), demonstrating that the vaccine induced an antibody response (148-153). A more recent study by Ong et al. demonstrated that a $\geq 2$ fold increase in mumps antibodies 30-days post-vaccination was considered to be an adequate response of immunity (154). Vaccine effectiveness (i.e., seroconversion post-vaccination) of 2 vaccine doses has only been conducted on the JL strain; 6 studies provided a median vaccine efficacy of $88 \%$. These studies have shown that 2 doses of MMR were more effective (but not statistically significant) than a single MMR dose to combat the incidence of mumps infection (101, 126, 145, 151, 152, 155). 
Mumps-specific antibodies have been detected 1-2 years postvaccination and without substantial decline for 8 years after mumps vaccination, with the immunogenicity and efficacy of the MMR vaccine showing comparable immunogenicity levels to post-vaccination levels at 3 years $(148,156)$. However, most studies of this vaccine (involving either a mumps-specific vaccine or a combined vaccine) only followed-up to 30-56 days postvaccination (157-167). Despite few follow-up studies estimating post-vaccination antibody titers specific to the vaccine mumps strain, the evidence of seroconversion post-vaccination in a number of studies indicate that primary vaccine failure does not seem to be a significant contributor to the outbreaks that have been recently observed $(118,149,150,152,158,168-171)$.

It has been noted that a small percentage of the population do not seroconvert post-vaccination; $<1 \%$ who received the MMR vaccine were seronegative 4-9 years after the first dose of MMR ( $n=616)$ (143). Poor immune responses to primary vaccination has been shown to be a good indicator of infection susceptibility (172). This is in agreement with the correlation of pre-outbreak JL virus neutralization titres and ELISA results being significantly lower in individuals who became infected compared to non-infected individuals (173). Further studies of these individuals may provide insights of which immunological process are integral to develop immunity.

\section{Secondary Vaccine Failure}

The current methods used to determine immunity against mumps cannot discriminate between primary and secondary vaccine failure; only the timing of these tests can assess whether an individual ever mounted an immune response postvaccination or whether the response is detectable years postvaccination. Primary vaccine failure encompasses the failure to mount an immune response to a dose of a vaccine, secondary vaccine failure refers to a more gradual loss of immunity after a successful initial response that occurs over a number of years post-vaccination (174). Several factors have been proposed to be implicated with secondary vaccine failure, such as waning immunity, a lack of cross-neutralization, and natural boosting.

\section{Waning Immunity}

Waning immunity is defined as a decline in immunological protection proportional to time since vaccination. Potential waning immunity has been documented in the current mumps outbreaks seen in Europe and the USA, mostly affecting young adults within highly vaccinated populations attending tertiary education who have received two doses of the MMR vaccine in early childhood (40, 110, 126, 144, 145, 175-181).

A number of studies from the USA, where a JL vaccine has been used since 1971 have demonstrated waning immunity within the population. The risk of developing clinical mumps was shown to increase by $10-27 \%$ for every year post-MMR vaccination (125), with the rates of mumps infection rising from 1.6 cases per 1,000 in those who received the second dose of the vaccine within 2 years of the outbreak, to 11.3 cases per 1,000 in those who received it over 13 years prior. Using a mathematical model with analytical limitations, a recent metaanalysis of six studies estimated that vaccine-derived immune protection to $\mathrm{MuV}$ wanes about 27 years post-vaccination (182). Kennedy et al. (183) also demonstrated a decrease of $~ 20 \%$ in mumps neutralizing antibody titers over 10 years.

In contrast, other studies appear to contradict, these findings, showing no link between mumps protection and time elapsed following administration of mumps vaccine $(138,148,149,184$, 185). LeBaron et al. (143) and Gothefors et al. (186) demonstrated that $70-99 \%$ of individuals still had detectable anti-mumps antibodies $\sim 10$ years after initial vaccination. Cohen et al. (101) also demonstrated minimal antibody level decline after two MMR doses 6-7 years after second vaccination. Neutralizing antibodies against the JL- 5 vaccine strain has also been detected in $\sim 80 \%$ for age groups $2-20$ years, $67 \%$ for age group $24-26$ years; and $77 \%$ for age group $50+$ years (187).

Implementation of a third dose of the MMR vaccine has been shown to be effective as a stop gap measure in limiting disease spread in outbreak settings situations (129). Individuals vaccinated for the third time had a $78 \%$ lower risk of contracting mumps, with a decreased attack rate of 6.7 vs. 14.5 cases per 1,000 when compared to those who received a second dose. More than $50 \%$ of those who received a third dose of the MMR vaccine showed a 4-fold increase in mumps antibody titers (105, 106, 168, 188). An increase in mumps IgG humoral immunity was also observed post-vaccine administration. However, this immunity boost has been shown to be a transient effect, with mumps antibody titers returning to pre-third dose of mumps-vaccination levels 1 year after vaccination.

Therefore, as waning immunity is thought to be an important factor facilitating mumps outbreaks, the emphasis placed on the quantity/quality of mumps-specific antibodies may need to be re-assessed. It is yet undetermined if the total loss of detectable antibodies correlates to a loss of clinical protection, as the minimal level of neutralizing antibody required for protection against mumps has not yet been defined (184).

\section{Cross-Neutralization}

Antigenic variation and thus reduced cross-neutralization between the vaccine and circulating strains of different $\mathrm{MuV}$ genotypes have been cited as possible explanations for mumps outbreaks in highly vaccinated populations $(125,184,189-191)$. Recent outbreaks in Europe and Northern America (including Ireland) have shown the circulating $\mathrm{MuV}$ during the current outbreaks to be genotype $\mathrm{G}(135,184,192,193)$. This $\mathrm{MuV}$ genotype was first identified in 1996, and has demonstrated intra-genotype diversity of up to $7 \%$ (Table 1) $(6,134)$.

The JL vaccine strain (genotype A), differs phylogenetically to the circulating $\mathrm{MuV}$ (genotype $\mathrm{G}$ ) (125). In vitro studies of the genotypic distribution and temporal shift of $\mathrm{MuV}$ suggest that cross neutralization between wild type and vaccine genotypes may be approximately half the concentration measured against the vaccine strain (130). Pre-infection neutralization titers in mumps positive cases were also significantly lower against genotype $G$ vs. mumps vaccine strain, potentially due to amino acid differences in B-cell epitopes and/or N-linked glycosylation sites on the HN and also within the F protein (194). Santak et al. $(195,196)$ also demonstrated that conformational changes within the F protein may lead to immunological escape. 
Despite the decline/scarcity of cross-neutralizing antibodies, different mumps vaccines used worldwide have been shown to prevent significant clinical mumps infection during outbreaks (101, 197). Dependent on the strain, a 2-16-fold variation of patient sample titers has been shown to be protective in in vitro plaque reduction neutralizations $(149,151,198)$. Although the sera of one of these studies, was collected only 6 weeks after MMR vaccination, a time point that may not signify the concept of waning immunity and antigenic differences, several other groups have shown that the most divergent strains of $\mathrm{MuV}$ can be neutralized in vitro with only slight variations in titers, supporting the concept that $\mathrm{MuV}$ is serotypically monotypic $(184,190,195,198)$. Epitopes of the MuV that are presented to CD8+ T-cells have been shown to be present in not only the circulating strains of virus but also in a number of vaccine strains (199). In addition, Lewnard et al. (182) also found no evidence that recent mumps outbreaks were due to the emergence of $\mathrm{MuV}$ strains escaping vaccine-driven immunological pressure.

Therefore, the limited data does not suggest that antigenic drift of the $\mathrm{MuV}$ leading to diminished neutralization capacity of the vaccine strain could fully explain the recent outbreaks (125). Further studies into the cross-neutralizing capacity of the mumps vaccine strain administered 15-20 years previously to the current circulating strain of $\mathrm{MuV}$ in countries where outbreaks are being observed will allow better deductions to be made. It is possible that differences in the neutralization capacity of vaccine-induced antibodies against different $\mathrm{MuV}$ strains may be more significant when levels of neutralizing antibody are low and become "overwhelmed" when the mumps viral load challenge is high (200).

\section{Natural Boosting}

Several prominent MMR/mumps vaccine studies were undertaken at a time when there was still a high prevalence of circulating wild type virus, which enabled sub-clinical boosting to occur in an individual. Such natural boosting is illustrated in Belarus, where a subpopulation of vaccinated individuals only had a small amount of their overall mumps IgG antibody levels specific to the vaccine-strain (201). Neutralization antibodies against Iowa-G/USA06 (the circulating wild type virus) were also present in pre-infection plasma of all mumps cases during a recent outbreak in the US (173). This indicates that the mumps vaccine alone is not solely responsible for the high levels of mumps antibodies (202), and that longterm antibody persistence or protective efficacy data of the vaccines used may not truly reflect the current circumstance of viral transmission/circulating within a highly vaccinated population (99).

Herd immunity increases the chance for natural mumps boosting for an individual is at a minimum, reducing the potential of the frequency of mumps outbreaks $(123,124,184)$. With less opportunity for subclinical boosting (asymptomatic response to the circulating virus), the impact of other elements of waning immunity may play an increasingly critical role in the re-emergence of mumps outbreaks $(98,171)$. Additionally, as the heterogeneous uptake of vaccines in this modern era is leading to susceptible individuals within the community, future work will need to encompass genotyping of circulating $\mathrm{MuV}$ to examine how impactful subclinical boosting was on early measures of vaccine efficacy in current populations.

\section{LABORATORY DETERMINANTS OF AN EFFECTIVE IMMUNE RESPONSE TO MUMPS VACCINE}

\section{Why Do We Consider Antibodies to Be the Best Measurement of Vaccine Efficacy?}

The evolution of an individual's immune response differs between natural infection and vaccination, in particular the difference in the affinity and specificity of an immunological marker such as antibodies (203).

True correlates of mumps immunity after vaccination have been poorly characterized; to date, there are no reliable correlates of protection from either symptomatic mumps infection (clinical immunity), or individuals previously exposed to $\mathrm{MuV}$ (204). Therefore, a serological surrogate/ substitute is used (205). Mumps vaccine efficacy is quantified by a single measure, IgG which may not suffice to evaluate the magnitude of the actual humoral response. Borgmann et al. (206) proposed an increase in mumps-specific IgG titer in sera as a diagnostic criteria of mumps reinfection (206). It has been suggested that vaccinated individuals have modified $\mathrm{B}$-cell responses to $\mathrm{MuV}$ that allow for the rapid generation of IgG antibodies and a blunted or absent IgM response $(207,208)$. In addition, emerging data in Simian Immunodeficiency Virus studies suggests that not all antibody responses are equal, and qualitative features of antibodies may be key to defining protective immune profiles (209).

Despite its use, the correlation to mumps-specific IgG concentrations and neutralization titers against the JL virus is poor, suggesting that IgG concentrations do not adequately represent a sufficient surrogate correlate of protection (194). This is demonstrated in Finland; only $24 \%$ of vaccinees had no detectable mumps antibodies after 21 years $(123,124)$. Data from the European Sero-Epidemiology Network (ESEN2) project in 2004 reported that MMR immunization uptake in Ireland in 2004 was $92 \%$ (6), however it was also suggested that only $80-$ $85 \%$ of 15 - to 24 -year-olds in Ireland had detectable antibodies to $\mathrm{MuV}$ by either natural immunity or immunization (210). In 2011, vaccine coverage of medical students in Germany was reported to be $75.1 \%$ (211). In children between the ages of 1-17 years, where $88.8 \%$ had been vaccinated with the MMR vaccine at least once, only $76.8 \%$ showed prevalence of antibodies (212). However, $7.8 \%$ showed a prevalence of antibodies to measles and rubella in the absence of mumps-specific antibodies. Therefore, previous measurement of anti-mumps-specific IgG that represented immunity induced by the mumps vaccine appears to be overestimated $(99,213)$.

Antibody levels of other components of the MMR vaccine have seen similar trends. Waning rubella antibody titers have been observed, despite the number of acute rubella and congenital rubella syndrome cases not increasing. It has also been shown that college students who received rubella vaccination during childhood and had low/no antibody response were able 
to mount a secondary response when challenged with rubella indicating that an individual's low antibody levels are not always indicative of susceptibility to infection (214). Measles antibodies can also be detected for up to a decade post-vaccination, with $>90 \%$ of individuals still measles IgG positive at 6-7 years of age $(144,215)$. However, as with mumps and rubella, waning measles antibody titers have been observed $(143,216)$. Despite this, a recent longitudinal study of up to 10 years demonstrates how effective the MMR vaccine has been in preventing diagnosed measles cases during the 1990's/2000's (217).

Similarly, three doses of the Hepatitis B (HBV) vaccine in a cohort of Alaskan natives showed $>95 \%$ seroconversion in children and young adult post-vaccination and provided long term and durable protection against chronic HBV infection. Although no increase of HBV prevalence were observed 51\% individuals had low to undetectable antibody levels after 30 years.

These observations suggest that an individual's antibody levels do not indicate susceptibility to infection, that either an antibody titer lower than recommended guidelines is still protective, or/and is an ineffective surrogate of protection. This is emphasized in a study by Amanna et al.; (218) responses to non-replicating protein antigens (tetanus and diphtheria) were shown to have approximate antibody half-lives of 11-19 years. In comparison, antibodies following wild type infection were shown to have half-lives of 50 years or more which was thought until recently to confer a more prolonged lifelong protection (214, $218,219)$. However, reinfections observed in individuals that were previously naturally infected have demonstrated that the quantitative measurement of antibodies do not indicate sterile immunity (220).

It is also important to stress that seroconversion rates due to immunization/natural infection only reflects a change of antibody status from negative to positive, but not necessarily the intensity of antibody response. In addition, there is no consistency in the timing of sample collected post-vaccination to test vaccine efficacy, and between the serological tests utilized for detecting mumps antibodies. As a result, documented seroconversion rates of the mumps vaccines used vary widely (JL: 74-100\%, RIT 4385 strain: 88-98\%, Urabe Am 9: 79-100\%, Rubini: 35-95\%).

This highlights that the assays used to detect immunity to $\mathrm{MuV}$ may not always detect an adequate post-vaccination response. Only a small number of serological commercial assays such as the detection of Hepatitis B surface antibody (anti-HBs) (221) and rubella IgG (222) have been designed using WHO reference material as a standard for quantification. However, even utilizing this reference standard demonstrates significant differences in the determined quantification of either anti-HBs or rubella IgG depending on the assays used; although a value for anti-HBs of $10 \mathrm{IU} / \mathrm{ml}$ is regarded as protective against significant $\mathrm{HBV}$ infection, the detection of this anti-HBs is significantly influenced by which anti-HBs assays is used (223-227). Therefore, it is possible that the current assays/tests mechanisms utilized to measure mumps antibodies are too insensitive/inappropriate/crude to identify nuances in the immune response which could correlate with immunity against mumps. In addition, variation within neutralization epitopes i.e., the quality of the antibody present could be a more important correlate than quantity $(190,198)$.

\section{Are There Better Correlates of Protection?}

Though labor-intensive, neutralizing antibodies are considered to be a better correlate of mumps immunity. Antibodies against the haemagglutinin-neuraminidase protein (HN) and nucleoprotein (NP) have been shown to neutralize $\mathrm{MuV}$, however, repeated attempts to define a titer that provides a protective threshold titer have been inconclusive (203, 228). In older studies, during field evaluations of the JL vaccine, neutralizing antibody titers of 1:2-1:4 in unvaccinated individuals was considered seropositive and protective from mumps infection $(149,151,152)$. Using a more contemporary wild-type isolate (Iowa-G/USA06), a 1:8 neutralizing titer cut off was defined between case patients and exposed patients, despite the fact that no cut-off could fully discern between the two groups (173). However, that these results are dependent on the challenge virus strain used in the assay. Rasheed et al. demonstrated a 6fold lower neutralization titer to the G-genotype when compared to the JL vaccine strain in 18-23 year olds (229). This has also been seen between mumps vaccine strains vs. circulating strains in India and China $(47,197)$. Despite studies in more highly vaccinated populations demonstrating that $\mathrm{HN}$-inhibiting titers after natural disease were 1:9 compared to 1:5 post-vaccination, neither appeared to prevent reinfection (173, 218-220, 230). There is increasing evidence that the mumps-specific antibody response is broader than neutralization alone (112). Avidity testing for virus-specific IgG has been proposed (3, 220, 229).

\section{Is Lymphoproliferative Immunity a Better Correlate of Protection?}

Individuals who lack measurable mumps-specific antibody levels may be susceptible to infection but protected from significant illness as they may be protected by cell-mediated immune memory. Prolonged T-cell responses are reported after other vaccinations; $14-16$ years after a single dose of the rubella vaccine RA27/3, a T-cell proliferative response to neutralizing antibodyinducing peptides suggest $\mathrm{T}$ helper and $\mathrm{B}$-cell interactions. This indicates that full vaccine effectiveness could be dependent on mounting both an antibody and cell-mediated immune response (214).

Although cell mediated immunity has not been as wellassessed in mumps infection, a lymphoproliferative response was induced in infants vaccinated at 6, 9, or 12 months of age was induced (231) with antigen-specific T-cells reported to appear within 1 month of infection (183). Lymphoproliferative responses to measles and mumps vaccine viruses were shown to persist in two thirds of the population at least 6 years after immunization (232), with T- and B-cell immunity persisting for 10 years post-immunization (202).

Low levels of mumps-specific memory B-cells have also been documented suggesting that mumps infection or vaccination may not generate a robust B-cell memory $(136,233)$. Two principal mechanisms for maintaining long-term humoral immunity have been proposed and reviewed by Amanna et al. (218): associations between memory B-cell levels and 
antibody may reflect an epiphenomenon in which serum antibody levels and memory B-cells are equally stable but independently maintained. If memory B-cells and plasma cells are independently regulated, then multiple re-exposures to antigens may cause divergence between memory B-cell levels and antibody levels (218). Antigens with the highest rates of boosting through vaccination or latent viral infection coincidentally showed the weakest association between memory B-cell titers and antibody titers (234).

Although the role and efficacy of T-cell immunity to mumps infection is unclear, there is a possibility that certain $\mathrm{MuV}$ strains may be capable of escaping vaccine induced T-cell responses, which may not be considered of significance until B-cell waning immunity comes into play (198). In individuals who did not respond to vaccination (i.e., had a $\leq 2$-fold of mumps antibody titers 30 days post-vaccination), several genes including those implicated in antigen presenting, processing, T-cell response and function showed significantly increased expression, with MHC Class II HLA-DRB3 and HLA-DRA, and CD86 induced when compared to responders 1 day post-MMR vaccination. This may indicate that the stimulation of a rapid adaptive immune response limits antigenic presentation and hence prevent the differentiation of memory B-cells to antibody-producing plasma cells (154).

Differences in predicted B-cell and T-cell epitopes between JL5 vaccine strain and other vaccine strains may also be implicated in the outbreaks witnessed (235). Although, it has also been shown that natural mumps infection or vaccination do not always induce both cellular and humoral immunity. de Wit et al. $(199,236,237)$ has shown the presence of Th1-type CD4 ${ }^{+}$ T-cells recognizing a $\mathrm{MuV}$ epitope in a HLR-DR restricted manner. In addition, the response of IFN- $\gamma$ and TNF producing $\mathrm{CD}^{+}{ }^{+} \mathrm{T}$-cells specific to $\mathrm{MuV}$ epitopes are lower in vaccinated individuals when compared to individuals who were naturally infected (199, 213, 236-238). Utilizing current knowledge and new technologies may help define a better surrogate correlate of protection and potentially determine a cut-off between the immunity of a vaccinated individual and a secondary mumps infection. This may potentially move the diagnostic preference from serological tests to more comprehensive functional assays.

\section{Why Vaccinate If You Cannot Define Protection?}

Despite the large resurgence of mumps outbreaks, there is insurmountable evidence highlighting the benefit of the mumps vaccine (Table 2). Routine childhood MMR vaccination has resulted in a dramatic decrease in the incidence of mumps cases, and has shifted the peak age-specific attack rates from a young children (manifesting between 5 and 15 years) to one that affects young adults, in particular those who have close interaction with other young adults $(18-24$ years) $(6,110)$. Additionally, clinical manifestations and severity of disease in vaccinated vs. unvaccinated individuals differ $(129,248)$. Although $\mathrm{MuV}$ can be clinically asymptomatic in about $15-30 \%$ of those who become infected, the vaccine against mumps confers protection in a dose response manner; unvaccinated individuals saw an attack rate of
TABLE 2 | Differences between Mumps vaccinated and unvaccinated persons.

Vaccinated Not vaccinated

\begin{tabular}{lll}
\hline Symptoms $(7,101,239,240)$ & Milder & Severe \\
Transmission $(197,241,242)$ & Low & High \\
Mumps viral load and replication $(243-245)$ & Low & High \\
Mumps isolation rates $(135,239)$ & Low & High \\
Duration of viral shedding $(244)$ & Shorter & Lasts Longer \\
Asymptomatic infection $(135,246,247)$ & $66 \%$ & $15-40 \%$ \\
\hline
\end{tabular}

Despite evidence of mumps infection in a vaccinated population, there is evidence to suggest a less severe clinical manifestation of the viral infection.

$31.8-42.9 \%$, whilst one dose and two doses of the JL vaccine were $4-13.6 \%$ and $2.2-3.6 \%$, respectively $(135,219,246)$.

Based on the reduction seen upon the introduction of a mumps vaccine, it has been proposed that MMR vaccination also prevents the transmission of the virus. There is limited knowledge regarding the shedding and transmission of $\mathrm{MuV}$, but it is thought that close contact and transmission of a certain viral load may induce clinical symptoms (243, 246, 249). Modeling data suggests that infectious $\mathrm{MuV}$ shedding decreases rapidly after the onset of symptoms, however $8-15 \%$ are patients are thought to still be virally shedding 5 days after the onset of symptoms (244). This could be the reason why the transmission of $\mathrm{MuV}$ can be exacerbated by close social situations within a heterogeneously vaccinated population. Outbreaks generally occur in situations of intense contact such as college dormitories, boarding schools, and youth summer camps (191), with up to a third reporting some contact with a mumps case (105).

Evidence of lower levels of viral replication also suggests a clinical benefit of the vaccine $(243,244)$. Viral load and presence of the mumps vaccine genome in areas of viral replication was lower in vaccinated individuals vs. unvaccinated individuals (243). In addition, patients who contracted mumps but had two doses of MMR have been shown to shed less $\mathrm{MuV}$ in their urine, with fewer experiencing bilateral parotitis or orchitis than unvaccinated individuals (239), This suggests that immunity induced by MMR vaccination limits virus transmission and complications $(241,242)$.

It should be noted also that individuals who received two doses of MMR, and had a positive correlation between viremia, salivary viral loads and systematic clinical mumps infection may have an increased risk of transmitting virus. These individuals also lacked mature functional responses, with low neutralizing antibody titers and avidity indexes (239).

Overall, evidence demonstrates a clinical advantage to receiving a mumps vaccine (Table 2). Currently no global consensus exists for the measurement of mumps antibodies, mumps avidity or neutralizing titers that correlate to vaccine response and protection in healthy individuals. If a biomarker is discovered, it could be utilized as an international diagnostic reference standard to allow global harmonization and evaluation of the relative effectiveness of the different vaccination programs worldwide. Such an attempt was conducted by Andrews et al. (250), who reported on the European Sero-Epidemiology Network project which was established to harmonize the 
seroepidemiology of five vaccine preventable infections including measles, mumps, and rubella in eight European countries. The study concluded that the development of an international standard for mumps would help in the standardization and comparability of mumps antibodies in the different enzyme immunoassays used in laboratories. However, to date, no international reference standard for mumps has been established.

\section{Can Improvements to Vaccines Be Made?}

In response to infection, the human immune system launches a series of immunological responses with the goal of controlling or eliminating the pathogen. If the pathogen circumvents the frontline defense of the innate immune system, an adaptive immune response specific for the pathogen will become activated to respond, with the intention to generate humoral- and cell-mediated immunity. Humoral immunity, represented by antibodies secreted by B-cells are not effective against pathogens that invade host cells. Therefore, cell-mediated immunity instructed by the innate immune system are additionally necessary and consist of $\mathrm{B}$-cells and T-cells. The unique compositions of the B-cell receptor and T-cell receptors specific for the invading pathogen proliferate and gain effector functions based on the antigen fragments presented on antigen presenting cell by MHC class II molecules. The activated Th-cell produces cytokines, resulting in the activation of macrophages (Th1 help), B-cells (Th2 help, called plasma cells), or cytotoxic T-cells. While most plasma cells, produce and secrete large amounts of antibodies, some differentiate into memory cells [reviewed in $(251,252)]$.

Vaccination aims to stimulate the host immunological process and formation of cell-mediated immunological memory via the use of live-attenuated or of inactivated/subunit vaccine components to promote a cell-mediated immune response. Extensive knowledge gaps significantly hinder improvements to the mumps vaccine and prospects for mumps eradication and maintaining proficient population immunity $(3,122,187)$. Few studies have collected data that examines different aspects of mumps immunity and are limited in their predictive value for future outbreaks (253). For example, the importance of $\mathrm{T}$ and B-cell responses in protective mumps immunity and how memory/plasma cell numbers are homeostatically maintained post-infection or vaccination is relatively unknown (252). It should be acknowledged that the mechanism of protection of infection may not be the same mechanism of recovery from infection, which may make the identification of a common correlate of protection and recovery difficult (203). Therefore, if a correlate or surrogate correlate is unobtainable to define an individual's protection to mumps, should we re-consider and re-focus efforts on optimizing the vaccine using available historical clinical and trial data?

\section{Administration}

It has been suggested that wild-type infection could confer a "better quality," broader and prolonged immuno-activation than vaccine-induced immunity. This is reflected in mean neutralizing antibody titers detected post-mumps vaccination, which were over five times lower than those detected following wild type infection. Similarly, hemagglutination-inhibiting titers after natural disease were 1:9 compared to $1: 5$ post-vaccination $(214,218,219)$.

The use of a live-attenuated virus vaccine is intended to mimic immunological reactions and responses between the host and wild type virus (254). The current liveattenuated MMR vaccine is intramuscularly injected, a route that significantly differs from the natural infection mode of transmission. However, emphasized by differing immunological kinetics between immunized and naturally infected individuals when subjected to wild type pathogens, injectable vaccines are considered not to be the best inducer of antigen-specific mucosal immune responses for mucosal pathogens, especially if the mode of administration is not the natural route (the respiratory tract) $(255,256)$. Improvements on a broader range of antigen delivery systems will improve vaccination strategies and potentially prolong the effect of a vaccination by producing a localized immunological response in the relevant tissues (257, 258).

Mucosal vaccines such as intra-nasal vaccination have advantages over traditional injectable vaccines as they can induce an effective, more robust immune response without any physical discomfort and more closely replicate the natural route of infection for mumps $(255,259)$. B-cells induced by the mucosal response are also capable of secreting IgA class of antibodies in the lumen, where the interaction and neutralization of specific antigens form IgA-antigen complexes are easily able to be entrapped in the mucus and eliminated by cilial epithelial cells (259). Activated mucosal lymphocytes can also reach other mucosal sites via the lymphatic system and have the capability to transfer immunity (260).

Such an example is the intranasal immunization of inactivated influenza. With a 70-90\% similar efficacy between the injectable and intranasal influenza in healthy individuals this intranasal vaccine can elicit the secretion of haemagglutinin and neuraminidase specific IgA antibodies in the upper respiratory tract, and corresponding IgG antibodies (258). Live, cold adapted attenuated nasal influenza vaccine has been routinely used in Russia for over 50 years (261). Other liquid live-attenuated intranasal vaccines are available; "Nasovac ${ }^{\circledR}$ " in India, and "FluMist ${ }^{\circledR}$ " in the US, UK and New Zealand $(258,259,262)$.

\section{Development of Improved Vaccines}

Inactivated vaccines consisting of heat/chemical or liveattenuating monovalent or multivalent pathogens in animals/cell lines were developed to protect against disease causing microorganisms (263). Less emphasis was placed on understanding the mechanisms related to conferring immunological memory; the focus lay on the availability, mass production and administration of the vaccine to introduce herd immunity into populations (264).

Currently, the least expensive and time effective method to licensure is the comparison of serologic responses of the new vaccine to an existing licensed vaccine, which can lead to a bias on the development of novel vaccines (222). This methodology also does not account for the fact that each vaccine developed elicits 
its own immunological signature and may need to be considered on an individual basis (265).

Raymond et al. (266) has suggested that embryonated chicken egg-based vaccines may induce antibodies that are more preferential to egg adapted strains better than wild type virus. Amino acid substitutions/differences in key antigenic targets due to the passage of the growing virus within this environment may optimize the growth of the virus, but could lead to differences over time that could affect the immunogenicity or potency of the vaccine $(172,222,267)$. The JL vaccine contains two isolates of the JL Strain (JL2 and JL5) and whilst no immunological differences have been documented, JL2 grows to higher titers than JL5 in embryonic eggs and also demonstrates significant sequence variability $(94,268)$. Zost et al. (269) also demonstrated that an egg selected mutation within a glycosylation site in the 2016-2017 influenza vaccine strain led to the production of poorer neutralizing antibodies to the vaccine strain compared to wild type influenza virus.

Vaccine RIT 4385 strain derived from one of the two distinct virus subtypes of the JL vaccine (JL5) showed comparable seroconversion rates despite inducing a significantly lower geometric mean antibody titer when compared to recipients of the JL vaccine, but does not have any longitudinal trials investigating its efficacy, even though there are populations who are currently receiving it $(101,270)$.

The significant time gap between pathogen emergence and vaccine licensure, could potentially lead to antigenic drift. There is potential that modern biotechnologies could be utilized to design novel vaccine platforms $(251,271,272)$. Clinically derived recombinant $\mathrm{MuV}$ lacking the expression of the immunomodulatory $\mathrm{V}$ or $\mathrm{SH}$ protein are currently being investigated (273). In China, a vaccine consisting of the prevalent wildtype virus genotype $(\mathrm{F})$ has recently been produced and is currently undergoing trials (269).

In addition, despite being extremely pleomorphic, utilizing MHC epitopes as potential B-cell and T-cell vaccine candidates are also being investigated $(81,274,275)$. Vaccine design has involved the utilization and templating of epitopes that previously induced a B-or T-cell response during natural disease that are considered to be immunogenic enough to induce similar responses if administered in a vaccine. However, the appropriate $\mathrm{B}$-cell and $\mathrm{T}$-cell epitope/peptide candidates to induce a protective immunological response can be difficult to correctly identify and synthesize, as it may differ to the immunodominant epitope and host presentation of that antigen (251, 276). Prediction of MHC-peptide binding and cleavage has demonstrated mismatches in both vaccine $\mathrm{T}$ cell and B-cell epitopes in vaccinated individuals highlighting small number of distinguishing amino acid changes of the JL5 major strain (235). The importance of understanding Tand B-cell responses and how antigen-specific memory cells numbers are homeostatically maintained post-infection is crucial to understand to ensure successful vaccine development (252, 277).

Since the 1990's, significant progress has also been made in developing flexible, amplifiable, scalable, inexpensive, and cold-chain free RNA vaccines, such as synthetic mRNA molecules encoding only the antigen of interest and selfamplifying RNA (sa-RNA) (264). Such examples include an experimental mRNA vaccine candidate (mRNA-1273) which encodes a stable form of the SARS-CoV-2 spike protein and has been accepted as a trial candidate for clinical trials in healthy male and female individuals $(278,279)$. In addition, sa-RNA viruses as gene delivery and vaccine vectors have also demonstrated therapeutic efficacy in a number of preclinical studies. In the context of influenza, sa-RNA vaccines have shown comparable results of protection at lower doses than mRNA vaccines $(272,280,281)$.

Exponential developments in the "OMIC" area has enabled further vaccine development and understanding of the immunological response and challenges surrounding this area (282). Systems vaccinology, which includes immunoformatics, DNA/RNAseq, microarrays, mass spectrometry proteomics, transcriptomics, and metabolomics have all shown huge potential in elucidating differences in vaccine strains, vaccine growth and individual response in depth and on an epigenetic level allowing the identification of new vaccine antigens with increased speed and sensitivity $(235,263,283-285)$.

Adjuvants, a group of biological and chemical compounds could also be considered to enhance and improve the longevity of the immune response of a vaccine such as the MMR. Adjuvants have been successful in significantly reducing overall antigen dose in vaccine formulations as well as alter and broaden the host response through epitope spreading and qualitatively shaping the effector function of antibodies through subclass selection $(173,286)$.

The re-purposing of live-attenuated vaccines as TIbV are also being investigated. Trained Immunity based Vaccines (TIbV) elicit heterologous protective effects by inducing a broader, lasting priming of innate immune cells, in addition to the intended specific immunological response and memory of conventional vaccines [reviewed in (287)]. MMR and BCG vaccines have been considered as potential TIbV in the context of the current coronavirus disease 2019 (COVID-19) pandemic (288), however further research is needed.

\section{Potency of Virus}

The mumps component of a vaccine is an unpurified product whose potency is measured through a biological assay for the substance rather than through evaluation of integrity of physical form (quantitative PCR after cell culture) (289). A monovalent mumps vaccine lot is used to characterize the performance of the mumps potency assay with international reference standards. Degradation products are neither identified nor quantified (290). Currently, the minimum potency of the mumps vaccine used varies between brands used [summarized by $\mathrm{Su}$ et al. (107)] (291). However, this potency measurement differs to other MMR vaccines strains previously used [reviewed in (10)]. In addition, the maximum required potency is not usually specified. Atrasheuskaya et al. (172) demonstrated that the four out of 14 lots of vaccine associated with six cases of viral transmission postvaccination to previously vaccinated contacts were in fact twice as potent as the lots that were not associated with viral transmission post-vaccination $(172,292)$. This may impact the use and efficacy 
of specific vaccines. Due to their neurovirulence and increased incidence of aseptic meningitis and mumps cases, the Urabe Am 9 and Rubini mumps vaccine strains were discontinued in many countries $(87,293,294)$.

Comparing alternative culturing technologies and defining a viral potency range for vaccines could help reduce variability within the MMR vaccine (292). Ensuring the use of a reference sample that had similar replication rate and composition as the virus to be tested will allow accurate determination of the quantity of virus present per lot of vaccine. Investigating novel vaccine candidates shown to induce a similar quantity but qualitatively different antibodies will help segregate and reveal potential correlates of protection (209). Incorporating more modern technologies such as microarray technology or antibody pattern/profiling (rather than single antibody measures) to investigate biomarkers of neutralizing antibody response and/or correlates of protective immunity, in addition to incorporating what has been accomplished in Finland will allow further understanding of mumps immunity $(123,124,173,195,196,295)$.

\section{Are the Current Perceptions of What Is Expected of a Vaccine Skewing the Overall Benefits It Elicits?}

The efficacy of a vaccine is defined by disease prevention (sterile immunity, establishment of primary infection and shedding of mature virus particle), or complications associated with infection (orchitis, neurological issues etc.) (203). Despite the well-documented success of the global immunization programs demonstrating how vaccines significantly attenuate disease and onward transmission of infection, they are rarely totally efficacious (demonstrated in pre-licensure clinical trials) or effective (determined by practical use) $(99,173,296)$.

Therefore, does "immunity" refer to sterile immunity or solely to protection from symptomatic infection? What defines an effective vaccine, or what constitutes vaccine failure? Does the medical profession and the "pro-vaccine" message contribute to the public skepticism regarding immunization? Is it time to shift the medical and public perception paradigm from "protection of infection following vaccination" to "protection from serious clinical mumps manifestation"?

The lack of definition leads to misinterpretation by health professionals and media of what is truly occurring. Such an example is currently observed with influenza; individuals who have recently being vaccinated against influenza and subsequently become infected with influenza, assume that the vaccine has "failed" even though there is a reduction in symptoms.

The current assertion that vaccines "protect against" or "eliminate" the risk of infection may contribute to the misperception about what level of protection a vaccine actually provides (vaccination efficacy) perpetuated by the witnessing of visible clinical disease and outbreaks despite vaccination (116, 297, 298). Therefore, definition and consensus of what is termed a true "vaccine failure" is required to inform both the clinical and public perception of what the function of a vaccine is.
Deciding what the clinical endpoint of a vaccine is i.e., infection with mild clinical symptoms vs. natural infection/disease with its associated complications and assessing the impact of the vaccine in a heterogeneously vaccinated population will allow a better consensus of what is required.

A paradigm shift in what is considered to be a good vaccine i.e. one that provides protection against serious clinical sequalae, in addition to identifying a reliable laboratory marker for this protection is required (203). By focusing on, and acknowledging that vaccines may not prevent infection but will attenuate the clinical complications/consequences that arise from infection in addition to reducing onward transmission will provide a more realistic view of the benefits of vaccination (297). Immunity is therefore beneficial but does not necessarily mean protection.

\section{DISCUSSION}

If we can decide whether the end point of a vaccine is either the prevention of infection or protection against serious sequalae of infection, its efficacy and impact can be determined and will have enormous implications on how vaccine failure can be studied, quantified and interpreted. This teasing out of the immunological response to $\mathrm{MuV}$ will ultimately provide potential correlates with robust predictive power, suggest directions for further vaccine improvement, and enable the discovery of potential biomarkers to help create a more efficient diagnostic assay that can discern between different infectious diseases and vaccination vs. disease status. The identification and incorporation of a correlate into diagnostic protocols which can be widely accessible may potentially allow global harmonization of criteria defining immunological protection against mumps.

The medical and scientific field needs to inform the public more accurately about what a good vaccine consists of, which may result in a more positive attitude toward vaccines. In the majority of individuals, a vaccine can prevent serious clinical sequalae and associated complications following wild type infections, but also significantly reduce onwards transmission in particular to the cohorts who are not vaccinated due to a contraindication to vaccination. This is the positive and realistic view of vaccination which should be presented rather than the current flawed message of "get the vaccine and be protected from infection." The public deserves, and will appreciate, a more accurate and informed message.

\section{AUTHOR CONTRIBUTIONS}

$\mathrm{AC}, \mathrm{JC}$, and JH contributed to the conception and design of the review. AC wrote the first draft of the manuscript. JC, TL, and $\mathrm{JH}$ contributed to manuscript revision. All authors have read and approved the submitted version.

\section{FUNDING}

This work was funded by the National Children's Research Centre, Children's Health Ireland, Dublin, Ireland with grant number $\mathrm{C} / 18 / 11$ awarded to $\mathrm{JH}$. 


\section{REFERENCES}

1. Hviid A, Rubin S, Muhlemann K. Mumps. Lancet. (2008) 371:93244. doi: 10.1016/S0140-6736(08)60419-5

2. Cantell K. Mumps virus. Adv Virus Res. (1961) 8:12364. doi: 10.1016/S0065-3527(08)60684-3

3. Narita M, Matsuzono Y, Takekoshi Y, Yamada S, Itakura O, Kubota M, et al. Analysis of mumps vaccine failure by means of avidity testing for mumps virus-specific immunoglobulin G. Clin Diagn Lab Immunol. (1998) 5:799-803. doi: 10.1128/CDLI.5.6.799-803.1998

4. Simpson RE. Infectiousness of communicable diseases in the household (measles, chickenpox, and mumps). Lancet. (1952) 2:549-54. doi: 10.1016/S0140-6736(52)91357-3

5. Hall R, Richards H. Hearing loss due to mumps. Arch Dis Child. (1987) 62:189-91. doi: 10.1136/adc.62.2.189

6. Carr MJ, Moss E, Waters A, Dean J, Jin L, Coughlan S, et al. Molecular epidemiological evaluation of the recent resurgence in mumps virus infections in Ireland. J Clin Microbiol. (2010) 48:3288-94. doi: 10.1128/JCM.00434-10

7. Ennis FA, Jackson D. Isolation of virus during the incubation period of mumps infection. J Pediatr. (1968) 72:5367. doi: 10.1016/S0022-3476(68)80347-6

8. Wilson RL, Fuentes SM, Wang P, Taddeo EC, Klatt A, Henderson AJ, et al. Function of small hydrophobic proteins of paramyxovirus. J Virol. (2006) 80:1700-9. doi: 10.1128/JVI.80.4.1700-1709.2006

9. Johansson B, Tecle T, Orvell C. Proposed criteria for classification of new genotypes of mumps virus. Scand J Infect Dis. (2002) 34:3557. doi: 10.1080/00365540110080043

10. Beleni AI, Borgmann S. Mumps in the vaccination age: global epidemiology and the situation in Germany. Int J Environ Res Public Health. (2018) 15:1618. doi: 10.3390/ijerph15081618

11. Bilkis MD, Barrero PR, Mistchenko AS. Measles resurgence in Argentina: 1997-8 outbreak. Epidemiol Infect. (2000) 124:28993. doi: $10.1017 /$ S0950268899003659

12. Pan American Health Organisation. Immunization: Coverage Data. (2020). Available online at: https://www.paho.org/en/topics/immunization (accessed May 11, 2020).

13. Ministry of Health Argentina. Triple Viral/Double Viral. (2020). Available online at: https://www.argentina.gob.ar/salud/vacunas/doble-triple-viral (accessed May 11, 2020).

14. Pan American Health Organisation. Immunization: Coverage Data of MMR1 and MMR2. (2020). Available online at: http://ais.paho.org/imm/IM_JRF_ COVERAGE.asp (accessed May 11, 2020).

15. Ministerio de Salud Argentina. National Vaccination Calender. (2020). Available online at: http://www.msal.gob.ar/images/stories/ryc/graficos/ 0000001386cnt-2019_calendario-nacional-vacunacion.jpg (accessed May $11,2020)$.

16. infobae.com. Everything You Need to Know About the New Vaccination Law in Argentina. (2018). Available online at: https://www.infobae.com/salud/ 2018/12/17/todo-lo-que-tenes-que-saber-de-la-nueva-ley-de-vacunacionen-argentina/ (accessed May 11, 2020).

17. Palacios G, Jabado O, Cisterna D, de Ory F, Renwick N, Echevarria JE, et al. Molecular identification of mumps virus genotypes from clinical samples: standardized method of analysis. J Clin Microbiol. (2005) 43:186978. doi: 10.1128/JCM.43.4.1869-1878.2005

18. Jin L, Orvell C, Myers R, Rota PA, Nakayama T, Forcic D, et al. Genomic diversity of mumps virus and global distribution of the 12 genotypes. Rev Med Virol. (2015) 25:85-101. doi: 10.1002/rmv.1819

19. World Health Organization. Mumps Reported Cases (As of $10 \mathrm{Dec} 2019$ ). (2019) Available online at: https://apps.who.int/immunization_monitoring/ globalsummary/timeseries/tsincidencemumps.html (accessed May 11, 2020).

20. Austrailian Government Department of Health. 2.7 Mumps (Last Updated 19 December 2013). (2013) Available online at: https://wwwl.health.gov.au/ internet/publications/publishing.nsf/Content/cda-cdi37suppl.htm/sim02vpds\sim2-7-mumps (accessed May 11, 2020).

21. Cooley L. Mumps Laboratory Case Definitnion; Version 1.0. (2020). Available online at: https:/www1.health.gov.au/internet/main/
publishing.nsf/Content/0FCCCA91ED937F22CA257F0700150816/

|protect\T1\textdollarFile/mumps.pdf (accessed May 11, 2020).

22. Austrailian Institute of Health and Welfare. Mumps in Austrailia. (2020). Available online at: https://www.aihw.gov.au/getmedia/c275433d-4ac84968-8207-ee48f07118da/aihw-phe-236_Mumps.pdf.aspx (accessed May $11,2020)$.

23. Trent MJ, Zhang EJ, Chughtai AA, MacIntyre CR. Parental opinions towards the "No Jab, No Pay" policy in Australia. Vaccine. (2019) 37:52506. doi: 10.1016/j.vaccine.2019.07.066

24. Westphal DW, Eastwood A, Levy A, Davies J, Huppatz C, Gilles M, et al. A protracted mumps outbreak in Western Australia despite high vaccine coverage: a population-based surveillance study. Lancet Infect Dis. (2019) 19:177-84. doi: 10.1016/S1473-3099(18)30498-5

25. Santos EMD, Noronha TG, Alves IS, Cruz RLS, Ferroco CLV, Brum RC, et al. Immunogenicity and safety of the combined vaccine for measles, mumps, and rubella isolated or combined with the varicella component administered at 3-month intervals: randomised study. Mem Inst Oswaldo Cruz. (2019) 114:e180517. doi: 10.1590/0074-02760180517

26. Sociedade Brasileira de Imunizações. Calendários de Vacinação SBIm 20192020. (2020). Available online at: https://sbim.org.br/images/calendarios/ calend-pg-crianca-adolesc-0-19.pdf (accessed May 11, 2020).

27. Ministério da Saúde do Brasil. Informe Tecnico Introducao Vacina Tetraviral 2013. Vacina Sarampo, Caxumba, Rubéola e Varicela (Atenuada). (2013). Available online at: http://www.saude.gov.br/images/pdf/2015/junho/ 26/Informe-T--cnico-da-Introdu----o-da-Vacina-Tetra-Viral-2013.pdf (accessed May 11, 2020).

28. Dourado I, Cunha S, Teixeira MG, Farrington CP, Melo A, Lucena $\mathrm{R}$, et al. Outbreak of aseptic meningitis associated with mass vaccination with a urabe-containing measles-mumps-rubella vaccine: implications for immunization programs. Am J Epidemiol. (2000) 151:524-30. doi: 10.1093/oxfordjournals.aje.a010239

29. da Cunha SS, Rodrigues LC, Barreto ML, Dourado I. Outbreak of aseptic meningitis and mumps after mass vaccination with MMR vaccine using the Leningrad-Zagreb mumps strain. Vaccine. (2002) 20:110612. doi: $10.1016 / \mathrm{S} 0264-410 \mathrm{X}(01) 00438-8$

30. Santos CL, Ishida MA, Foster PG, Sallum MA, Benega MA, Borges DB, et al. Detection of a new mumps virus genotype during parotitis epidemic of 2006-2007 in the state of Sao Paulo, Brazil. J Med Virol. (2008) 80:3239. doi: 10.1002/jmv.21068

31. Urbano PR, Fujita DM, Romano CM. Reemergence of mumps in Sao Paulo, Brazil-the urgent need for booster shot campaign to prevent a serious infectious disease. Rev Soc Bras Med Trop. (2017) 50:5358. doi: 10.1590/0037-8682-0320-2016

32. Government of Canada. Guidelines for the Prevention and Control of Mumps Outbreaks in Canada (Archived). Mumps-Containing Vaccine and Immunization Programs in Canada. (2009) Available online at: https:/www.canada.ca/en/public-health/services/reports-publications/ canada-communicable-disease-report-ccdr/monthly-issue/2010-36/ guidelines-prevention-control-mumps-outbreaks-canada/immunization. html (accessed May 11, 2020).

33. Government of Canada. Guidelines for the Prevention and Control of Mumps Outbreaks in Canada. Mumps-Containing Vaccine and Immunization Programs in Canada. Available online at: https://www.canada.ca/en/publichealth/services/reports-publications/canada-communicable-diseasereport-ccdr/monthly-issue/2010-36/guidelines-prevention-controlmumps-outbreaks-canada/immunization.html (accessed May 11, 2020).

34. Public Health Ontario. Immunization Coverage Report for School Pupils in Ontario. 2016-17 School Year. Toronto, ON: Queen's Printer for Ontario (2018). Available online at: https://www.publichealthontario.ca/-/media/ documents/I/2018/immunization-coverage-2016-17.pdf?la=en (accessed May 11, 2020).

35. Dubey V, Ozaldin O, Shulman L, Stuart R, Maclachlan J, Bromley L, et al. Investigation and management of a large community mumps outbreak among young adults in Toronto, Canada, January 2017-February 2018. Can Commun Dis Rep. (2018) 44:309-16. doi: 10.14745/ccdr.v44i12a01

36. Canada Communicable Disease Report. Guidelines: Mumps in Canada. (2010). Available online at: https://www.canada.ca/en/public-health/ services/reports-publications/canada-communicable-disease-report-ccdr/ 
monthly-issue/2010-36/guidelines-prevention-control-mumps- outbreakscanada.html (accessed May 11, 2020).

37. Cui A, Zhu Z, Mao N, Si Y, Ma Y, Hu Y, et al. Assessment of onedose mumps-containing vaccine effectiveness on wild-type genotype $\mathrm{F}$ mumps viruses circulating in mainland China. Vaccine. (2018) 36:572531. doi: 10.1016/j.vaccine.2018.08.028

38. Cui A, Zhu Z, Hu Y, Deng X, Sun Z, Zhang Y, et al. Mumps epidemiology and mumps virus genotypes circulating in mainland China during 2013-2015. PLoS ONE. (2017) 12:e0169561. doi: 10.1371/journal.pone.0169561

39. Liu W, Deng L, Lin X, Wang X, Ma Y, Deng Q, et al. Importation of mumps virus genotype K to China from Vietnam. Emerg Infect Dis. (2018) 24:774-8. doi: 10.3201/eid2404.170591

40. Vygen S, Fischer A, Meurice L, Mounchetrou Njoya I, Gregoris $\mathrm{M}$, Ndiaye B, et al. Waning immunity against mumps in vaccinated young adults, France 2013. Euro Surveill. (2016) 21:30156. doi: 10.2807/1560-7917.ES.2016.21.10.30156

41. Medscape. Pediatric Vaccines: Global Brands and Country Availability. (2018). Available online at: https://emedicine.medscape.com/article/ 2500038-overview\#a5 (accessed May 11, 2020).

42. Santé Publique France. Mumps. (2019) Available online at: https://www. santepubliquefrance.fr/maladies-et-traumatismes/maladies-a-preventionvaccinale/oreillons (accessed May 11, 2020).

43. World Health Organization. Information Sheet Observed Rate of Vaccine Reactions. Measles, Mumps and Rubella Vaccines. World Health Organization (2014).

44. World Health Organization. 2019: Routine Immunization: Regional and Country Profiles; France. Summary of Routine Immunization and VaccinePreventable Diseases Surveillance Data, Based Primarily on Data for 2017 Submitted Through the WHO/UNICEF Joint Reporting Form on Immunization. (2019). Available online at: http://www.euro.who.int/_data/ assets/pdf_file/0020/420653/FRA.pdf?ua=1 (accessed May 11, 2020).

45. Antona D, Levy-Bruhl D, Baudon C, Freymuth F, Lamy M, Maine C, et al. Measles elimination efforts and 2008-2011 outbreak, France. Emerg Infect Dis. (2013) 19:357-64. doi: 10.3201/eid1903.121360

46. Hellenbrand W, Siedler A, Tischer A, Meyer C, Reiter S, Rasch G, et al. Progress toward measles elimination in Germany. J Infect Dis. (2003) 187(Suppl 1):S208-16. doi: 10.1086/368046

47. Zengel J, Phan SI, Pickar A, Xu P, He B. Immunogenicity of mumps virus vaccine candidates matching circulating genotypes in the United States and China. Vaccine. (2017) 35:3988-94. doi: 10.1016/j.vaccine.2017. 05.084

48. World Health Organization. 2019: Routine Immunization: Regional and Country Profiles; Germany. Summary of Routine Immunization and VaccinePreventable Diseases Surveillance Data, Based Primarily on Data for 2017 Submitted Through the WHO/UNICEF Joint Reporting Form on Immunization. (2019). Available online at: http://www.euro.who.int/_data/ assets/pdf_file/0013/420520/DEU.pdf?ua=1 (accessed May 11, 2020).

49. European Medicines Agency (EMA). List of the Names, Pharmaceutical Forms, Strengths of the Medicinal Products, Routes of Administration, Marketing Authorisation Holders in the Member States (Annex 1, Article 31). (2013) Available online at: https://www.ema.europa.eu/en/documents/ referral/monovalent-multivalent-measles-mumps-rubella/varicellavaccines-article-31-referral-annex-i_en.pdf (accessed May 11, 2020).

50. Galazka AM, Robertson SE, Kraigher A. Mumps and mumps vaccine: a global review. Bull World Health Organ. (1999) 77:3-14.

51. Naim HY. Live attenuated measles mumps and rubella vaccines: an over view. Int J Vaccines Vaccin. (2015) 1:1-6. doi: 10.15406/ijvv.2015.01.00005

52. Gabutti G, Guido M, Rota MC, De Donno A, Ciofi Degli Atti ML, Crovari P, et al. The epidemiology of mumps in Italy. Vaccine. (2008) 26:290611. doi: 10.1016/j.vaccine.2008.03.040

53. Ciofi Degli Atti ML, Salmaso S, Bella A, Arigliani R, Gangemi $\mathrm{M}$, Chiamenti G, et al. Pediatric sentinel surveillance of vaccinepreventable diseases in Italy. Pediatr Infect Dis J. (2002) 21:7638. doi: 10.1097/00006454-200208000-00013

54. Ministry of Health Italy. Vaccine Law. (2018) Available online at: http:// www.salute.gov.it/portale/vaccinazioni/dettaglioContenutiVaccinazioni.jsp? lingua $=$ italiano\&id $=4824 \&$ are $=$ =vaccinazioni $\&$ menu $=$ vuoto $($ accessed May $11,2020)$.

55. D’Ancona F, D’Amario C, Maraglino F, Rezza G, Iannazzo S. The law on compulsory vaccination in Italy: an update
2 years after the introduction. Euro Surveill. 24:1900371. doi: 10.2807/1560-7917.ES.2019.24.26.1900371

56. Wakefield AJ. MMR vaccination and autism. Lancet. (1999) 354:94950. doi: 10.1016/S0140-6736(05)75696-8

57. European Centre for Disease Prevention and Control. 2020: Annual epidemiological report for 2017; Mumps. (2020). Available online at: https:// www.ecdc.europa.eu/sites/default/files/documents/mumps-2017-aer.pdf (accessed May 11, 2020).

58. Santos JI, Nakamura MA, Godoy MV, Kuri P, Lucas CA, Conyer RT. Measles in Mexico, 1941-2001: interruption of endemic transmission and lessons learned. J Infect Dis. (2004) 189(Suppl. 1):S243-50. doi: 10.1086/378520

59. Del Valle A, Garcia AA, Barron BL. Detection of mumps virus genotype H in two previously vaccinated patients from Mexico City. Arch Virol. (2016) 161:1639-44. doi: 10.1007/s00705-016-2770-6

60. Mokdad AH, Gagnier MC, Colson KE, Dansereau E, ZunigaBrenes P, Rios-Zertuche D, et al. Missed opportunities for measles, mumps, and rubella ( $\mathrm{mmr}$ ) immunization in mesoamerica: potential impact on coverage and days at risk. PLoS ONE. (2015) 10:e0139680. doi: 10.1371/journal.pone.0139680

61. Santos S. El programa nacional de vacunacion: orgullo de Mexico. Rev Fac Med UNAM. (2002). 142-53. Available online at: https://www.medigraphic. com/pdfs/facmed/un-2002/un023g.pdf

62. Onishchenko G, Ezhlova E, Gerasimova A, Tsvirkun O, Shulga S, Lipskaya G, et al. Progress toward measles elimination in the Russian Federation, 20032009. J Infect Dis. (2011) 204(Suppl. 1):S366-72. doi: 10.1093/infdis/jir083

63. World Health Organization. 2019: Routine Immunization: Regional and Country Profiles; Russian Federation. Summary of Routine Immunization and Vaccine-Preventable Diseases Surveillance Data, Based Primarily on Data for 2017 Submitted Through the WHO/UNICEF Joint Reporting Form on Immunization. (2019). Available online at: http://www.euro.who.int/_data/ assets/pdf_file/0007/420937/RUS-ENG.pdf (accessed May 11, 2020).

64. Atrasheuskaya AV, Kulak MV, Rubin S, Ignatyev GM. Mumps vaccine failure investigation in Novosibirsk, Russia, 2002-2004. Clin Microbiol Infect. (2007) 13:670-6. doi: 10.1111/j.1469-0691.2007.01727.x

65. Al-Mazrou Y, Tumsah S, Khalil M, Al-Jeffri M, Afzal MA, al-Ghamdy Y, et al. Safety evaluation of MMR vaccine during a primary school campaign in Saudi Arabia. J Trop Pediatr. (2002) 48:354-8. doi: 10.1093/tropej/48.6.354

66. Ministry of Health Saudi Arabia. National Immunisation Schedule. (2019) Available online at: https://www.moh.gov.sa/en/HealthAwareness/ EducationalContent/HealthTips/Documents/Immunization-Schedule.pdf (accessed May 11, 2020).

67. Khalil MK, Al-Mazrou YY, AlHowasi MN, Al-Jeffri M. Measles in Saudi Arabia: from control to elimination. Ann Saudi Med. (2005) 25:3248. doi: 10.5144/0256-4947.2005.324

68. Khalil MK, Al-Mazrou YY, Al-Jeffri M, Al-Ghamdy YS. Measles immunization in Saudi Arabia: the need for change. East Mediterr Health J. (2001) 7:829-34. Available online at: https://apps.who.int/iris/handle/10665/ 119096

69. Ministry of Health Saudi Arabia. Ministries of Health and Education Start a Vaccination Campaign against Measles, Mumps and Rubella. (2020). Available online at: https://www.moh.gov.sa/en/Ministry/MediaCenter/ News/Pages/News-2014-10-19-002.aspx (accessed May 11, 2020).

70. Choi KM. Reemergence of mumps. Korean J Pediatr. (2010) 53:6238. doi: 10.3345/kjp.2010.53.5.623

71. Kim ST, Kim YJ, Yang JS, Nam JG, Kim K, Kim SS, et al. Genetic characteristics of mumps viruses isolated in Korea from 2007 to 2012. J Med Virol. (2016) 88:1479-86. doi: 10.1002/jmv.24515

72. Choe YJ, Lee YH, Cho SI. Increasing mumps incidence rates among children and adolescents in the Republic of Korea: age-period-cohort analysis. Int $J$ Infect Dis. (2017) 57:92-7. doi: 10.1016/j.ijid.2017.02.011

73. Expat Guide Turkey. Compulsory Vaccines to be applied to Baby after Birth in Turkey. Available online at: https://www.expatguideturkey. com/compulsory-vaccines-to-be-applied-to-baby-after-birth-in-turkey/ (accessed May 11, 2020).

74. Arisoy ES, Çiftçi, E. The national vaccination schedule in previously healthy children: the practical recommendations about additional vaccines. J Pediatr Infect. (2014) 8:1-6. doi: 10.5152/ced.2014.0002

75. World Health Organization. 2019: Routine Immunization: Regional and Country Profiles; Turkey. Summary of Routine Immunization and VaccinePreventable Diseases Surveillance Data, Based Primarily on Data for 
2017 Submitted Through the WHO/UNICEF Joint Reporting Form on Immunization. (2019). Available online at: http://www.euro.who.int/_data/ assets/pdf_file/0004/367789/mr-cp-turkey-eng.pdf?ua=1 (accessed May 11, 2020).

76. Akcali A, Yilmaz N, Uyar Y, Ertek M, Buzgan T. Genotyping of mumps virus circulating in Turkey in the 2006-2007 winter season. Arch Virol. (2009) 154:1807-12. doi: 10.1007/s00705-009-0519-1

77. Miller E, Andrews N, Stowe J, Grant A, Waight P, Taylor B. Risks of convulsion and aseptic meningitis following measles-mumps-rubella vaccination in the United Kingdom. Am J Epidemiol. (2007) 165:7049. doi: 10.1093/aje/kwk045

78. National Health Service. NHS Vaccinations and When to Have Them. Available online at: https://www.nhs.uk/conditions/vaccinations/nhsvaccinations-and-when-to-have-them/ (accessed May 11, 2020).

79. World Health Organization. 2019: Routine Immunization: Regional and Country Profiles; United Kingdom of Great Britain and Northern Ireland. Summary of Routine Immunization and Vaccine-Preventable Diseases Surveillance Data, Based Primarily on Data for 2017 Submitted Through the WHO/UNICEF Joint Reporting Form on Immunization. (2019). Available online at: http://www.euro.who.int/_data/assets/pdf_file/0003/ 420654/GBR.pdf?ua=1 (accessed May 11, 2020).

80. National Health Service (NHS) Digital. Childhood Vaccination Coverage Statistics-England 2018-19. (2019) Available online at: https://digital.nhs.uk/ data-and-information/publications/statistical/nhs-immunisation-statistics/ england-2018-19 (accessed May 11, 2020).

81. Adamczyk-Poplawska M, Markowicz S, Jagusztyn-Krynicka EK. Proteomics for development of vaccine. J Proteomics. (2011) 74:2596-616. doi: 10.1016/j.jprot.2011.01.019

82. Lau RK, Turner MD. Viral mumps: increasing occurrences in the vaccinated population. Oral Surg Oral Med Oral Pathol Oral Radiol. (2019) 128:38692. doi: 10.1016/j.oooo.2019.06.012

83. Centre for Disease Control and Prevention. Recommended Child and Adolescent Immunization Schedule for Ages 18 Years or Younger, United States. (2020). Available online at: https://www.cdc.gov/vaccines/ schedules/hcp/imz/child-adolescent.html (accessed May 11, 2020).

84. Mellerson JL, Maxwell CB, Knighton CL, Kriss JL, Seither R, Black CL. Vaccination coverage for selected vaccines and exemption rates among children in kindergarten - United States, 2017-18 school year. MMWR Morb Mortal Wkly Rep. (2018) 67:1115-22. doi: 10.15585/mmwr.mm6740a3

85. Hill HA, Elam-Evans LD, Yankey D, Singleton JA, Kang Y. Vaccination coverage among children aged 19-35 months - United States, 2017. MMWR Morb Mortal Wkly Rep. (2018) 67:1123-8. doi: 10.15585/mmwr.mm6740a4

86. Muhlemann K. The molecular epidemiology of mumps virus. Infect Genet Evol. (2004) 4:215-9. doi: 10.1016/j.meegid.2004.02.003

87. Mclean HQ, Hickman CJ, Seward JF. The Immunological Basis for Immunization Series Module 16: Mumps. World Health Organization (2010).

88. Habel K. Vaccination of human beings against mumps; vaccine administered at the start of an epidemic. I. Incidence and severity of mumps in vaccinated and control groups. Am J Hyg. (1951) 54:295-311. doi: 10.1093/oxfordjournals.aje.a119487

89. Habel K. Preparation of mumps vaccines and immunization of monkeys against experimental mumps infection. Public Health Rep. (1946) 61:165564. doi: $10.2307 / 4585906$

90. European Centre for Disease Prevention and Control. Mumps: Vaccine Scheduler. Available online at: https://vaccine-schedule.ecdc.europa.eu/ Scheduler/ByDisease?SelectedDiseaseId=9\&SelectedCountryIdByDisease $=-$ 1 (accessed January 7, 2020).

91. European Centre for Disease Prevention and Control. Mumps: Recommended Vaccinations. (2018). Available online at: https://vaccineschedule.ecdc.europa.eu/Scheduler/ByDisease?SelectedDiseaseId=9\& SelectedCountryIdByDisease $=-1$ (accessed July 26, 2019).

92. Buynak EB, Hilleman MR. Live attenuated mumps virus vaccine. 1. Vaccine development. Proc Soc Exp Biol Med. (1966) 123:76875. doi: 10.3181/00379727-123-31599

93. Kaaijk P, van der Zeijst B, Boog M, Hoitink C. Increased mumps incidence in the Netherlands: review on the possible role of vaccine strain and genotype. Euro Surveill. (2008) 13:18914. Available online at: https://www. eurosurveillance.org/content/10.2807/ese.13.26.18914-en
94. Chambers P, Rima BK, Duprex WP. Molecular differences between two Jeryl Lynn mumps virus vaccine component strains, JL5 and JL2. J Gen Virol. (2009) 90(Pt 12):2973-81. doi: 10.1099/vir.0.013946-0

95. Afzal MA, Pickford AR, Forsey T, Heath AB, Minor PD. The Jeryl Lynn vaccine strain of mumps virus is a mixture of two distinct isolates. $J$ Gen Virol. (1993) 74(Pt 5):917-20. doi: 10.1099/0022-1317-74-5-917

96. Health Protection Surveillance Centre. Definition of an Outbreak. Available online at: https://www.hpsc.ie/notifiablediseases/casedefinitions/outbreak/ (accessed January 12, 2020).

97. Chamot E, Toscani L, Egger P, Germann D, Bourquin C. Estimation of the efficacy of three strains of mumps vaccines during an epidemic of mumps in the Geneva canton (Switzerland). Rev Epidemiol Sante Publique. (1998) 46:100-7.

98. Ong G, Goh KT, Ma S, Chew SK. Comparative efficacy of Rubini, JerylLynn and Urabe mumps vaccine in an Asian population. J Infect. (2005) 51:294-8. doi: 10.1016/j.jinf.2004.10.001

99. Latner DR, McGrew M, Williams NJ, Sowers SB, Bellini WJ, Hickman CJ. Estimates of mumps seroprevalence may be influenced by antibody specificity and serologic method. Clin Vaccine Immunol. (2014) 21:28697. doi: 10.1128/CVI.00621-13

100. Brockhoff HJ, Mollema L, Sonder GJ, Postema CA, van Binnendijk RS, Kohl RH, et al. Mumps outbreak in a highly vaccinated student population, The Netherlands, 2004. Vaccine. (2010) 28:2932-6. doi: 10.1016/j.vaccine.2010.02.020

101. Cohen C, White JM, Savage EJ, Glynn JR, Choi Y, Andrews N, et al. Vaccine effectiveness estimates, 2004-2005 mumps outbreak, England. Emerg Infect Dis. (2007) 13:12-7. doi: 10.3201/eid1301.060649

102. Schwarz NG, Bernard H, Melnic A, Bucov V, Caterinciuc N, an der Heiden $\mathrm{M}$, et al. Mumps outbreak in the Republic of Moldova, 2007-2008. Pediatr Infect Dis J. (2010) 29:703-6. doi: 10.1097/INF.0b013e3181d743df

103. Stein-Zamir C, Shoob H, Abramson N, Tallen-Gozani E, Sokolov I, Zentner G. Mumps outbreak in Jerusalem affecting mainly male adolescents. Euro Surveill. (2009) 14:19440. doi: 10.2807/ese.14.50.19440-en

104. Ferenczi A, Gee S, Cotter S, Kelleher K. Ongoing mumps outbreak among adolescents and young adults, Ireland, August 2018 to January 2020. Euro Surveill. (2020) 25:2000047. doi: 10.2807/1560-7917.ES.2020.25.4.2000047

105. Shah M, Quinlisk P, Weigel A, Riley J, James L, Patterson J, et al. Mumps outbreak in a highly vaccinated university-affiliated setting before and after a measles-mumps-rubella vaccination campaign-Iowa, July 2015-May 2016. Clin Infect Dis. (2018) 66:81-8. doi: 10.1093/cid/c ix718

106. Golwalkar M, Pope B, Stauffer J, Snively A, Clemmons N. Mumps outbreaks at four universities-Indiana, 2016. MMWR Morb Mortal Wkly Rep. (2018) 67:793-7. doi: 10.15585/mmwr.mm6729a1

107. Su SB, Chang HL, Chen AK. Current status of mumps virus infection: epidemiology, pathogenesis, and vaccine. Int J Environ Res Public Health. (2020) 17:1-15. doi: 10.3390/ijerph 17051686

108. Lam E, Rosen JB, Zucker JR. Mumps: an update on outbreaks, vaccine efficacy, and genomic diversity. Clin Microbiol Rev. (2020) 33:116. doi: 10.1128/CMR.00151-19

109. Sheikh S, Biundo E, Courcier S, Damm O, Launay O, Maes E, et al. A report on the status of vaccination in Europe. Vaccine. (2018) 36:497992. doi: 10.1016/j.vaccine.2018.06.044

110. Barskey AE, Glasser JW, LeBaron CW. Mumps resurgences in the United States: a historical perspective on unexpected elements. Vaccine. (2009) 27:6186-95. doi: 10.1016/j.vaccine.2009.06.109

111. Failure to vaccinate and vaccine failure. Nat Microbiol. (2019) 4:725. doi: 10.1038/s41564-019-0450-5

112. Jones DS, Podolsky SH, Greene JA. The burden of disease and the changing task of medicine. N Engl J Med. (2012) 366:23338. doi: 10.1056/NEJMp1113569

113. Porter D, Porter R. The politics of prevention: anti-vaccinationism and public health in nineteenth-century England. Med Hist. (1988) 32:23152. doi: $10.1017 /$ S0025727300048225

114. Glanz JM, Newcomer SR, Narwaney KJ, Hambidge SJ, Daley MF, Wagner $\mathrm{NM}$, et al. A population-based cohort study of undervaccination in 8 managed care organizations across the United States. JAMA Pediatr. (2013) 167:274-81. doi: 10.1001/jamapediatrics.2013.502 
115. World Health Organization. Meeting of the strategic advisory group of experts on immunization, October 2014-conclusions and recommendations. Wkly Epidemiol Rec. (2014) 89:561-76. Available online at: https://apps.who. int/iris/handle/10665/242296

116. Pluviano S, Watt C, Della Sala S. Misinformation lingers in memory: failure of three pro-vaccination strategies. PLOS ONE. (2017) 12:e0181640. doi: 10.1371/journal.pone.0181640

117. Feemster KA, Offit P. Delaying vaccination is not a safer choice. JAMA Pediatr. (2013) 167:1097-8. doi: 10.1001/jamapediatrics.2013.3071

118. Usonis V, Bakasenas V, Kaufhold A, Chitour K, Clemens R. Reactogenicity and immunogenicity of a new live attenuated combined measles, mumps and rubella vaccine in healthy children. Pediatr Infect Dis J. (1999) 18:428. doi: 10.1097/00006454-199901000-00011

119. Hviid A, Hansen JV, Frisch M, Melbye M. Measles, mumps, rubella vaccination and autism: a nationwide cohort study. Ann Intern Med. (2019) 170:513-20. doi: 10.7326/M18-2101

120. Mrozek-Budzyn D, Kieltyka A, Majewska R, Augustyniak M. Measles, mumps and rubella (MMR) vaccination has no effect on cognitive development in children-the results of the Polish prospective cohort study. Vaccine. (2013) 31:2551-7. doi: 10.1016/j.vaccine.2013.03.057

121. Health Protection Surveillance Centre. MMR. (2019). Available online at: https://www.hpsc.ie/a-z/vaccinepreventable/mmrprotectionagainstmeaslesmumpsrubella/ (accessed February 13, 2020).

122. Briss PA, Fehrs LJ, Parker RA, Wright PF, Sannella EC, Hutcheson RH, et al. Sustained transmission of mumps in a highly vaccinated population: assessment of primary vaccine failure and waning vaccine-induced immunity. J Infect Dis. (1994) 169:77-82. doi: 10.1093/infdis/169.1.77

123. Peltola H, Karanko V, Kurki T, Hukkanen V, Virtanen M, Penttinen $\mathrm{K}$, et al. Rapid effect on endemic measles, mumps, and rubella of nationwide vaccination programme in Finland. Lancet. (1986) 1:1379. doi: 10.1016/S0140-6736(86)92270-1

124. Peltola H, Jokinen S, Paunio M, Hovi T, Davidkin I. Measles, mumps, and rubella in Finland: 25 years of a nationwide elimination programme. Lancet Infect Dis. (2008) 8:796-803. doi: 10.1016/S1473-3099(08)70282-2

125. Ramanathan R, Voigt EA, Kennedy RB, Poland GA. Knowledge gaps persist and hinder progress in eliminating mumps. Vaccine. (2018) 36:37216. doi: 10.1016/j.vaccine.2018.05.067

126. Dayan GH, Quinlisk MP, Parker AA, Barskey AE, Harris ML, Schwartz JM, et al. Recent resurgence of mumps in the United States. N Engl J Med. (2008) 358:1580-9. doi: 10.1056/NEJMoa0706589

127. Centers for Disease Control and Prevention. Brief report: update: mumps activity-United States, January 1-October 7, 2006. MMWR Morb Mortal Wkly Rep. (2006) 55:1152-3. Available online at: https://www.cdc.gov/ $\mathrm{mmwr} /$ preview/mmwrhtml/mm5542a3.htm

128. Sartorius B, Penttinen P, Nilsson J, Johansen K, Jonsson K, Arneborn M, et al. An outbreak of mumps in Sweden, February-April 2004. Euro Surveill. (2005) 10:559. doi: 10.2807/esm.10.09.00559-en

129. Peltola H, Kulkarni PS, Kapre SV, Paunio M, Jadhav SS, Dhere RM. Mumps outbreaks in Canada and the United States: time for new thinking on mumps vaccines. Clin Infect Dis. (2007) 45:459-66. doi: 10.1086/520028

130. Kaaijk P, Gouma S, Hulscher HI, Han WG, Kleijne DE, van Binnendijk RS, et al. Dynamics of the serologic response in vaccinated and unvaccinated mumps cases during an epidemic. Hum Vaccin Immunother. (2015) 11:175461. doi: 10.1080/21645515.2015.1040967

131. Centers for Disease Control. Measles prevention. MMWR Suppl. (1989) 38:1-18.

132. Trotz-Williams LA, Mercer NJ, Paphitis K, Walters JM, Wallace D, Kristjanson E, et al. Challenges in interpretation of diagnostic test results in a mumps outbreak in a highly vaccinated population. Clin Vaccine Immunol. (2017) 24:1-7. doi: 10.1128/CVI.00542-16

133. Mankertz A, Beutel U, Schmidt FJ, Borgmann S, Wenzel JJ, Ziegler $\mathrm{P}$, et al. Laboratory-based investigation of suspected mumps cases submitted to the German National Reference Centre for Measles, Mumps, and Rubella, 2008 to 2013. Int J Med Microbiol. (2015) 305:61926. doi: 10.1016/j.ijmm.2015.08.011

134. Rota JS, Turner JC, Yost-Daljev MK, Freeman M, Toney DM, Meisel $\mathrm{E}$, et al. Investigation of a mumps outbreak among university students with two measles-mumps-rubella (MMR) vaccinations, Virginia, SeptemberDecember 2006. J Med Virol. (2009) 81:1819-25. doi: 10.1002/jmv.21557
135. Rota JS, Rosen JB, Doll MK, McNall RJ, McGrew M, Williams N, et al. Comparison of the sensitivity of laboratory diagnostic methods from a wellcharacterized outbreak of mumps in New York city in 2009. Clin Vaccine Immunol. (2013) 20:391-6. doi: 10.1128/CVI.00660-12

136. Latner DR, McGrew M, Williams N, Lowe L, Werman R, Warnock E, et al. Enzyme-linked immunospot assay detection of mumps-specific antibodysecreting B cells as an alternative method of laboratory diagnosis. Clin Vaccine Immunol. (2011) 18:35-42. doi: 10.1128/CVI.00284-10

137. Park DW, Nam MH, Kim JY, Kim HJ, Sohn JW, Cho Y, et al. Mumps outbreak in a highly vaccinated school population: assessment of secondary vaccine failure using IgG avidity measurements. Vaccine. (2007) 25:466570. doi: 10.1016/j.vaccine.2007.04.013

138. Hassan J, Dean J, Moss E, Carr MJ, Hall WW, Connell J. Seroepidemiology of the recent mumps virus outbreaks in Ireland. J Clin Virol. (2012) 53:3204. doi: 10.1016/j.jcv.2011.12.022

139. L'Huillier AG, Eshaghi A, Racey CS, Ogbulafor K, Lombos E, Higgins RR, et al. Laboratory testing and phylogenetic analysis during a mumps outbreak in Ontario, Canada. Virol J. (2018) 15:1-9. doi: 10.1186/s12985-018-0996-5

140. Centre for Disease Control and Prevention. Mumps. (2019) Available online at: https://www.cdc.gov/mumps/hcp.html\#:Isim:text=RT\%2DPCR\%20and \%20viral\%20culture,aid\%20in\%20diagnosing\%20mumps\%20infection (accessed July 8, 2020).

141. Hassan J, Connell AR, Leahy TR, Connell JC. Diagnosis of acute mumps infection during an outbreak in a highly vaccinated population: mumps RNA or mumps IgM detection? Global J Immunol Allergic Dis. (2018) 6:1-4. doi: 10.20941/2310-6980.2018.06.1

142. Dilcher M, Barratt K, Douglas J, Strathdee A, Anderson T, Werno A. Monitoring viral genetic variation as a tool to improve molecular diagnostics for mumps virus. J Clin Microbiol. (2018) 56:e0040518. doi: 10.1128/JCM.00405-18

143. LeBaron CW, Forghani B, Beck C, Brown C, Bi D, Cossen C, et al. Persistence of mumps antibodies after 2 doses of measles-mumps-rubella vaccine. J Infect Dis. (2009) 199:552-60. doi: 10.1086/596207

144. Davidkin I, Jokinen S, Broman M, Leinikki P, Peltola H. Persistence of measles, mumps, and rubella antibodies in an MMR-vaccinated cohort: a 20-year follow-up. J Infect Dis. (2008) 197:950-6. doi: 10.1086/528993

145. Cortese MM, Jordan HT, Curns AT, Quinlan PA, Ens KA, Denning PM, et al. Mumps vaccine performance among university students during a mumps outbreak. Clin Infect Dis. (2008) 46:1172-80. doi: 10.1086/529141

146. Rubin S, Kennedy R, Poland G. Emerging mumps infection. Pediatr Infect Dis J. (2016) 35:799-801. doi: 10.1097/INF.0000000000001182

147. Nelson GE, Aguon A, Valencia E, Oliva R, Guerrero ML, Reyes R, et al. Epidemiology of a mumps outbreak in a highly vaccinated island population and use of a third dose of measles-mumps-rubella vaccine for outbreak control-Guam 2009 to 2010. Pediatr Infect Dis J. (2013) 32:37480. doi: 10.1097/INF.0b013e318279f593

148. Weibel RE, Buynak EB, McLean AA, Hilleman MR. Long-term follow-up for immunity after monovalent or combined live measles, mumps, and rubella virus vaccines. Pediatrics. (1975) 56:380-7.

149. Weibel RE, Buynak EB, McLean AA, Roehm RR, Hilleman MR. Persistence of antibody in human subjects for 7 to 10 years following administration of combined live attenuated measles, mumps, and rubella virus vaccines. Proc Soc Exp Biol Med. (1980) 165:260-3. doi: 10.3181/00379727-165-40967

150. Isomura S, Asano Y, Hon AS, Miyata T, Suzuki S. Studies on live attenuated mumps vaccine. I. Comparative field trials with two different live vaccines. Biken J. (1973) 16:39-42

151. Hilleman MR, Weibel RE, Buynak EB, Stokes J Jr, Whitman JE Jr. Live attenuated mumps-virus vaccine. IV. Protective efficacy as measured in a field evaluation. N Engl J Med. (1967) 276:2528. doi: 10.1056/NEJM196702022760502

152. Weibel RE, Stokes J Jr, Buynak EB, Whitman JE Jr, Hilleman MR. Live attenuated mumps-virus vaccine. 3. Clinical and serologic aspects in a field evaluation. $N$ Engl J Med. (1967) 276:245-51. doi: 10.1056/NEJM196702022760501

153. Young ML, Dickstein B, Weibel RE, Stokes J Jr, Buynak EB, Hilleman MR. Experiences with Jeryl Lynn strain live attenuated mumps virus vaccine in a pediatric outpatient clinic. Pediatrics. (1967) 40:798-803.

154. Ong EZ, Gan ES, de Alwis R, Wijaya L, Ong XM, Zhang M, et al. Genomic signature of early T-cell response is associated with lower antibody 
titer threshold for sterilizing immunity. Antiviral Res. (2019) 166:3541. doi: 10.1016/j.antiviral.2019.03.013

155. Harling R, White JM, Ramsay ME, Macsween KF, van den Bosch C. The effectiveness of the mumps component of the MMR vaccine: a case control study. Vaccine. (2005) 23:4070-4. doi: 10.1016/j.vaccine.2004.10.020

156. Wellington K, Goa KL. Measles, mumps, rubella vaccine (Priorix; GSKMMR): a review of its use in the prevention of measles, mumps and rubella. Drugs. (2003) 63:2107-26. doi: 10.2165/00003495-20036319 $0-00012$

157. Klein NP, Abu-Elyazeed R, Povey M, Macias Parra M, Diez-Domingo J, Ahonen A, et al. Immunogenicity and safety of a measles-mumps-rubella vaccine administered as a first dose to children aged 12 to 15 months: a phase III, randomized, noninferiority, lot-to-lot consistency study. J Pediatric Infect Dis Soc. (2019) 9:194-201. doi: 10.1093/jpids/piz010

158. Lee CY, Tang RB, Huang FY, Tang H, Huang LM, Bock HL. A new measles mumps rubella (MMR) vaccine: a randomized comparative trial for assessing the reactogenicity and immunogenicity of three consecutive production lots and comparison with a widely used MMR vaccine in measles primed children. Int J Infect Dis. (2002) 6:2029. doi: 10.1016/S1201-9712(02)90112-8

159. Gillet Y, Steri GC, Behre U, Arsene JP, Lanse X, Helm K, et al. Immunogenicity and safety of measles-mumps-rubella-varicella (MMRV) vaccine followed by one dose of varicella vaccine in children aged 15 months2 years or 2-6 years primed with measles-mumps-rubella (MMR) vaccine. Vaccine. (2009) 27:446-53. doi: 10.1016/j.vaccine.2008.10.064

160. He H, Chen E, Chen H, Wang Z, Li Q, Yan R, et al. Similar immunogenicity of measles-mumps-rubella (MMR) vaccine administrated at 8 months versus 12 months age in children. Vaccine. (2014) 32:40015. doi: 10.1016/j.vaccine.2014.04.044

161. Santos EM, Silva e Sa GR, Siqueira MM, Martins Rde M, Camacho LA, von Doellinger Vdos R, et al. Immune response to the mumps component of the MMR vaccine in the routine of immunisation services in the Brazilian national immunisation program. Mem Inst Oswaldo Cruz. (2014) 109:3359. doi: 10.1590/0074-0276130351

162. Bavdekar A, Oswal J, Ramanan PV, Aundhkar C, Venugopal P, Kapse D, et al. Immunogenicity and safety of measles-mumpsrubella vaccine delivered by disposable-syringe jet injector in India: a randomized, parallel group, non-inferiority trial. Vaccine. (2018) 36:1220-6. doi: 10.1016/j.vaccine.2018.01.006

163. Mufson MA, Diaz C, Leonardi M, Harrison CJ, Grogg S, Carbayo A, et al. Safety and immunogenicity of human serum albumin-free MMR vaccine in US children aged 12-15 months. J Pediatric Infect Dis Soc. (2015) 4:33948. doi: 10.1093/jpids/piu081

164. Lalwani S, Chatterjee S, Balasubramanian S, Bavdekar A, Mehta S, Datta $S$, et al. Immunogenicity and safety of early vaccination with two doses of a combined measles-mumps-rubella-varicella vaccine in healthy Indian children from 9 months of age: a phase III, randomised, non-inferiority trial. BMJ Open. (2015) 5:e007202. doi: 10.1136/bmjopen-2014-007202

165. Li Volti S, Giammanco-Bilancia G, Grassi M, Garozzo R, Gluck R, Giammanco G. Duration of the immune response to MMR vaccine in children of two age-different groups. Eur J Epidemiol. (1993) 9:3114. doi: 10.1007/BF00146269

166. Knuf M, Zepp F, Helm K, Maurer H, Prieler A, Kieninger-Baum D, et al. Antibody persistence for 3 years following two doses of tetravalent measlesmumps-rubella-varicella vaccine in healthy children. Eur J Pediatr. (2012) 171:463-70. doi: 10.1007/s00431-011-1569-4

167. Czajka H, Schuster V, Zepp F, Esposito S, Douha M, Willems P. A combined measles, mumps, rubella and varicella vaccine (PriorixTetra): immunogenicity and safety profile. Vaccine. (2009) 27:650411. doi: 10.1016/j.vaccine.2009.07.076

168. McLean HQ, Fiebelkorn AP, Temte JL, Wallace GS, Centers for Disease Control and Prevention. Prevention of measles, rubella, congenital rubella syndrome, and mumps, 2013: summary recommendations of the Advisory Committee on Immunization Practices (ACIP). MMWR Recomm Rep. (2013) 62:1-34. Available online at: https://www.cdc.gov/mmwr/preview/ mmwrhtml/rr6204a1.htm

169. Wiedermann U, Garner-Spitzer E, Wagner A. Primary vaccine failure to routine vaccines: why and what to do? Hum Vaccin Immunother. (2016) 12:239-43. doi: 10.1080/21645515.2015.1093263
170. Vesikari T, Andre FE, Simoen E, Florent G, Ala-Laurila EL, Heikkinen A, et al. Evaluation in young children of the urabe Am 9 strain of live attenuated mumps vaccine in comparison with the Jeryl Lynn strain. Acta Paediatr Scand. (1983) 72:37-40. doi: 10.1111/j.1651-2227.1983.tb09660.x

171. Schwarzer S, Reibel S, Lang AB, Struck MM, Finkel B, Gerike E, et al. Safety and characterization of the immune response engendered by two combined measles, mumps and rubella vaccines. Vaccine. (1998) 16:298304. doi: 10.1016/S0264-410X(97)00174-6

172. Atrasheuskaya AV, Neverov AA, Rubin S, Ignatyev GM. Horizontal transmission of the Leningrad-3 live attenuated mumps vaccine virus. Vaccine. (2006) 24:1530-6. doi: 10.1016/j.vaccine.2005.10.009

173. Cortese MM, Barskey AE, Tegtmeier GE, Zhang C, Ngo L, Kyaw MH, et al. Mumps antibody levels among students before a mumps outbreak: in search of a correlate of immunity. J Infect Dis. (2011) 204:141322. doi: 10.1093/infdis/jir526

174. Michalik DE, Steinberg SP, Larussa PS, Edwards KM, Wright PF, Arvin AM, et al. Primary vaccine failure after 1 dose of varicella vaccine in healthy children. J Infect Dis. (2008) 197:944-9. doi: 10.1086/529043

175. Vandermeulen C, Roelants M, Vermoere M, Roseeuw K, Goubau P, Hoppenbrouwers K. Outbreak of mumps in a vaccinated child population: a question of vaccine failure? Vaccine. (2004) 22:27136. doi: 10.1016/j.vaccine.2004.02.001

176. Watson JC, Hadler SC, Dykewicz CA, Reef S, Phillips L. Measles, mumps, and rubella-vaccine use and strategies for elimination of measles, rubella, and congenital rubella syndrome and control of mumps: recommendations of the Advisory Committee on Immunization Practices (ACIP). MMWR Recomm Rep. (1998) 47:1-57.

177. Miller E, Hill A, Morgan-Capner P, Forsey T, Rush M. Antibodies to measles, mumps and rubella in UK children 4 years after vaccination with different MMR vaccines. Vaccine. (1995) 13:799-802. doi: 10.1016/0264-410X(94)00086-3

178. Davidkin I, Valle M. Vaccine-induced measles virus antibodies after two doses of combined measles, mumps and rubella vaccine: a 12-year follow-up in two cohorts. Vaccine. (1998) 16:2052-7. doi: 10.1016/S0264-410X(98)00081-4

179. Vandermeulen C, Clement F, Roelants M, Van Damme P, Hoppenbrouwers $\mathrm{K}$, Leroux-Roels G. Evaluation of cellular immunity to mumps in vaccinated individuals with or without circulating antibodies up to 16 years after their last vaccination. J Infect Dis. (2009) 199:1457-60. doi: 10.1086/5 98482

180. Date AA, Kyaw MH, Rue AM, Klahn J, Obrecht L, Krohn T, et al. Longterm persistence of mumps antibody after receipt of 2 measles-mumpsrubella (MMR) vaccinations and antibody response after a third MMR vaccination among a university population. J Infect Dis. (2008) 197:16628. doi: $10.1086 / 588197$

181. Broliden K, Abreu ER, Arneborn M, Bottiger M. Immunity to mumps before and after MMR vaccination at 12 years of age in the first generation offered the two-dose immunization programme. Vaccine. (1998) 16:3237. doi: 10.1016/S0264-410X(97)88332-6

182. Lewnard JA, Grad YH. Vaccine waning and mumps reemergence in the United States. Sci Transl Med. (2018) 10:eaao5945. doi: 10.1126/scitranslmed.aao5945

183. Kennedy RB, Ovsyannikova IG, Thomas A, Larrabee BR, Rubin S, Poland GA. Differential durability of immune responses to measles and mumps following MMR vaccination. Vaccine. (2019) 37:177584. doi: $10.1016 /$ j.vaccine.2019.02.030

184. Rubin SA, Qi L, Audet SA, Sullivan B, Carbone KM, Bellini WJ, et al. Antibody induced by immunization with the Jeryl Lynn mumps vaccine strain effectively neutralizes a heterologous wild-type mumps virus associated with a large outbreak. J Infect Dis. (2008) 198:50815. doi: $10.1086 / 590115$

185. Kenny L, O’Kelly E, Connell J, De Gascun C, Hassan J. Mumps outbreaks in a highly vaccinated population: investigation of a neutralization titre against the current circulating wildtype genotype G5 mumps virus. J Clin Virol. (2016) 74:8-12. doi: 10.1016/j.jcv.2015.11.023

186. Gothefors L, Bergstrom E, Backman M. Immunogenicity and reactogenicity of a new measles, mumps and rubella vaccine when administered as a second dose at 12 y of age. Scand J Infect Dis. (2001) 33:5459. doi: 10.1080/00365540110026593 
187. Vermeire T, Barbezange C, Francart A, Hamouda A, Litzroth A, Hutse $\mathrm{V}$, et al. Sera from different age cohorts in Belgium show limited crossneutralization between the mumps vaccine and outbreak strains. Clin Microbiol Infect. (2019) 25:907.e1-6. doi: 10.1016/j.cmi.2018.11.016

188. Cardemil CV, Dahl RM, James L, Wannemuehler K, Gary HE, Shah M, et al. Effectiveness of a third dose of MMR vaccine for mumps outbreak control. N Engl J Med. (2017) 377:947-56. doi: 10.1056/NEJMoa1703309

189. Orvell C, Tecle T, Johansson B, Saito H, Samuelson A. Antigenic relationships between six genotypes of the small hydrophobic protein gene of mumps virus. J Gen Virol. (2002) 83(Pt 10):2489-96. doi: 10.1099/0022-1317-83-10-2489

190. Rubin S, Mauldin J, Chumakov K, Vanderzanden J, Iskow R, Carbone K. Serological and phylogenetic evidence of monotypic immune responses to different mumps virus strains. Vaccine. (2006) 24:2662-8. doi: 10.1016/j.vaccine.2005.10.050

191. Latner DR, Hickman CJ. Remembering mumps. PLoS Pathog. (2015) 11:e1004791. doi: 10.1371/journal.ppat.1004791

192. Utz S, Richard JL, Capaul S, Matter HC, Hrisoho MG, Muhlemann K. Phylogenetic analysis of clinical mumps virus isolates from vaccinated and non-vaccinated patients with mumps during an outbreak, Switzerland 19982000. J Med Virol. (2004) 73:91-6. doi: 10.1002/jmv.20064

193. Afzal MA, Buchanan J, Dias JA, Cordeiro M, Bentley ML, Shorrock CA, et al. RT-PCR based diagnosis and molecular characterisation of mumps viruses derived from clinical specimens collected during the 1996 mumps outbreak in Portugal. J Med Virol. (1997) 52:349-53. doi: 10.1002/(sici)10969071(199708)52:4<349::aid-jmv1>3.0.co;2-1

194. Gouma S, Ten Hulscher HI, Schurink-van 't Klooster TM, de Melker HE, Boland GJ, Kaaijk P, et al. Mumps-specific cross-neutralization by MMR vaccine-induced antibodies predicts protection against mumps virus infection. Vaccine. (2016) 34:4166-71. doi: 10.1016/j.vaccine.2016.06.063

195. Santak M, Lang-Balija M, Ivancic-Jelecki J, Kosutic-Gulija T, Ljubin-Sternak S, Forcic D. Antigenic differences between vaccine and circulating wild-type mumps viruses decreases neutralization capacity of vaccine-induced antibodies. Epidemiol Infect. (2013) 141:1298-309. doi: 10.1017/S0950268812001896

196. Santak M, Orvell C, Gulija TK. Identification of conformational neutralization sites on the fusion protein of mumps virus. J Gen Virol. (2015) 96(Pt 5):982-90. doi: 10.1099/vir.0.000059

197. Vaidya SR, Dvivedi GM, Jadhav SM. Cross-neutralization between three mumps viruses \& mapping of haemagglutininneuraminidase (HN) epitopes. Indian J Med Res. (2016) 143:37-42. doi: 10.4103/0971-5916.178587

198. Rubin SA, Link MA, Sauder CJ, Zhang C, Ngo L, Rima BK, et al. Recent mumps outbreaks in vaccinated populations: no evidence of immune escape. J Virol. (2012) 86:615-20. doi: 10.1128/JVI.06125-11

199. de Wit J, Emmelot ME, Meiring H, van Gaans-van den Brink JAM, van Els C, Kaaijk $\mathrm{P}$. Identification of naturally processed mumps virus epitopes by mass spectrometry: confirmation of multiple CD8+ T-cell responses in mumps patients. J Infect Dis. (2020) 221:474-82. doi: 10.1093/infdis/jiz480

200. Smits G, Mollema L, Hahne S, de Melker H, Tcherniaeva I, Waaijenborg S, et al. Seroprevalence of mumps in The Netherlands: dynamics over a decade with high vaccination coverage and recent outbreaks. PLoS ONE. (2013) 8:e58234. doi: 10.1371/journal.pone.0058234

201. Atrasheuskaya AV, Blatun EM, Kulak MV, Atrasheuskaya A, Karpov IA, Rubin S, et al. Investigation of mumps vaccine failures in Minsk, Belarus, 2001-2003. Vaccine. (2007) 25:4651-8. doi: 10.1016/j.vaccine.2007. 04.020

202. Hanna-Wakim R, Yasukawa LL, Sung P, Arvin AM, Gans HA. Immune responses to mumps vaccine in adults who were vaccinated in childhood. J Infect Dis. (2008) 197:1669-75. doi: 10.1086/588195

203. Plotkin SA. Correlates of protection induced by vaccination. Clin Vaccine Immunol. (2010) 17:1055-65. doi: 10.1128/CVI.00131-10

204. Dhiman N, Ovsyannikova IG, Ryan JE, Jacobson RM, Vierkant RA, Pankratz VS, et al. Correlations among measles virus-specific antibody, lymphoproliferation and Th1/Th2 cytokine responses following measles-mumps-rubella-II (MMR-II) vaccination. Clin Exp Immunol. (2005) 142:498-504. doi: 10.1111/j.1365-2249.2005.0 2931.x
205. Vidor E. Evaluation of the persistence of vaccine-induced protection with human vaccines. J Comp Pathol. (2010) 142(Suppl. 1):S96-101. doi: 10.1016/j.jcpa.2009.10.021

206. Borgmann S, Schwab F, Santibanez S, Mankertz A. Mumps virus infection in vaccinated patients can be detected by an increase in specific IgG antibodies to high titres: a retrospective study. Epidemiol Infect. (2014) 142:238896. doi: 10.1017/S0950268813003427

207. Hatchette T, Davidson R, Clay S, Pettipas J, Leblanc J, Sarwal S, et al. Laboratory diagnosis of mumps in a partially immunized population: the nova scotia experience. Can J Infect Dis Med Microbiol. (2009) 20:e15762. doi: 10.1155/2009/493275

208. Maillet M, Bouvat E, Robert N, Baccard-Longere M, Morel-Baccard C, Morand P, et al. Mumps outbreak and laboratory diagnosis. J Clin Virol. (2015) 62:14-9. doi: 10.1016/j.jcv.2014.11.004

209. Pittala S, Bagley K, Schwartz JA, Brown EP, Weiner JA, Prado IJ, et al. Antibody Fab-Fc properties outperform titer in predictive models of SIV vaccine-induced protection. Mol Syst Biol. (2019) 15:e8747. doi: 10.15252/msb.20188747

210. Di Renzi M, Jackson S, Gee S, Cotter S. Increase in mumps in Ireland in late 2004. Euro Surveill. (2004) 8:2608. doi: 10.2807/esw.08.52.02608-en

211. Allwinn R, Zeidler B, Steinhagen K, Rohwader E, Wicker S, Rabenau HF, et al. Assessment of mumps virus-specific antibodies by different serological assays: which test correlates best with mumps immunity? Eur J Clin Microbiol Infect Dis. (2011) 30:1223-8. doi: 10.1007/s10096-011-1216-Z

212. Poethko-Muller C, Mankertz A. Seroprevalence of measles-, mumpsand rubella-specific IgG antibodies in German children and adolescents and predictors for seronegativity. PLOS ONE. (2012) 7:e42867. doi: 10.1371/journal.pone.0042867

213. Terada K, Hagihara K, Oishi T, Miyata I, Akaike H, Ogita S, et al. Cellular and humoral immunity after vaccination or natural mumps infection. Pediatr Int. (2017) 59:885-90. doi: 10.1111/ped.13306

214. Terada K, Itoh Y, Wakabayashi T, Teranishi H, Akaike H, Ogita S, et al. Rubella specific cell-mediated and humoral immunity following vaccination in college students with low antibody titers. Vaccine. (2015) 33:60938. doi: 10.1016/j.vaccine.2015.06.113

215. Seagle EE, Bednarczyk RA, Hill T, Fiebelkorn AP, Hickman CJ, Icenogle JP, et al. Measles, mumps, and rubella antibody patterns of persistence and rate of decline following the second dose of the MMR vaccine. Vaccine. (2018) 36:818-26. doi: 10.1016/j.vaccine.2017.12.075

216. Bautista-Lopez N, Ward BJ, Mills E, McCormick D, Martel N, Ratnam S. Development and durability of measles antigen-specific lymphoproliferative response after MMR vaccination. Vaccine. (2000) 18:1393-401. doi: 10.1016/S0264-410X(99)00396-5

217. Geier DA, Kern JK, Geier MR. Childhood MMR vaccination and the incidence rate of measles infection: a ten year longitudinal cohort study of American children born in the 1990s. BMC Pediatr. (2019) 19:325. doi: 10.1186/s12887-019-1710-5

218. Amanna IJ, Carlson NE, Slifka MK. Duration of humoral immunity to common viral and vaccine antigens. N Engl J Med. (2007) 357:190315. doi: 10.1056/NEJMoa066092

219. Dayan GH, Rubin S. Mumps outbreaks in vaccinated populations: are available mumps vaccines effective enough to prevent outbreaks? Clin Infect Dis. (2008) 47:1458-67. doi: 10.1086/591196

220. Gut JP, Lablache C, Behr S, Kirn A. Symptomatic mumps virus reinfections. J Med Virol. (1995) 45:17-23. doi: 10.1002/jmv.1890450104

221. Jenkins A, Minhas R, Morris C, Berry N. Complete genome sequence of the WHO international standard for hepatitis B virus DNA. Genome Announc. (2017) 5:1-2. doi: 10.1128/genomeA.01576-16

222. Ward BJ, Pillet S, Charland N, Trepanier S, Couillard J, Landry N. The establishment of surrogates and correlates of protection: useful tools for the licensure of effective influenza vaccines? Hum Vaccin Immunother. (2018) 14:647-56. doi: 10.1080/21645515.2017.1413518

223. Wainwright RB, McMahon BJ, Bulkow LR, Hall DB, Fitzgerald MA, Harpster AP, et al. Duration of immunogenicity and efficacy of hepatitis B vaccine in a Yupik Eskimo population. JAMA. (1989) 261:23626. doi: 10.1001/jama.261.16.2362

224. Simons BC, Spradling PR, Bruden DJ, Zanis C, Case S, Choromanski $\mathrm{TL}$, et al. A longitudinal hepatitis $\mathrm{B}$ vaccine cohort demonstrates 
long-lasting hepatitis B virus (HBV) cellular immunity despite loss of antibody against HBV surface antigen. J Infect Dis. (2016) 214:27380. doi: 10.1093/infdis/jiw142

225. Bruce MG, Bruden D, Hurlburt D, Zanis C, Thompson G, Rea L, et al. Antibody levels and protection after hepatitis B vaccine: results of a 30year follow-up study and response to a booster dose. J Infect Dis. (2016) 214:16-22. doi: 10.1093/infdis/jiv748

226. Wainwright RB, McMahon BJ, Bulkow LR, Parkinson AJ, Harpster AP. Protection provided by hepatitis B vaccine in a Yupik Eskimo population. Seven-year results. Arch Intern Med. (1991) 151:16346. doi: 10.1001/archinte.151.8.1634

227. Xu ZY, Duan SC, Margolis HS, Purcell RH, Ou-Yang PY, Coleman PJ, et al. Long-term efficacy of active postexposure immunization of infants for prevention of hepatitis B virus infection. United States-People's Republic of China Study Group on Hepatitis B. J Infect Dis. (1995) 171:5460. doi: $10.1093 /$ infdis/171.1.54

228. Mauldin J, Carbone K, Hsu H, Yolken R, Rubin S. Mumps virus-specific antibody titers from pre-vaccine era sera: comparison of the plaque reduction neutralization assay and enzyme immunoassays. J Clin Microbiol. (2005) 43:4847-51. doi: 10.1128/JCM.43.9.4847-4851.2005

229. Rasheed MAU, Hickman CJ, McGrew M, Sowers SB, Mercader S, Hopkins A, et al. Decreased humoral immunity to mumps in young adults immunized with MMR vaccine in childhood. Proc Natl Acad Sci USA. (2019) 116:190716. doi: 10.1073/pnas.1905570116

230. Nojd J, Tecle T, Samuelsson A, Orvell C. Mumps virus neutralizing antibodies do not protect against reinfection with a heterologous mumps virus genotype. Vaccine. (2001) 19:1727-31. doi: 10.1016/S0264-410X(00)00392-3

231. Gans H, Yasukawa L, Rinki M, DeHovitz R, Forghani B, Beeler J, et al. Immune responses to measles and mumps vaccination of infants at 6,9 , and 12 months. J Infect Dis. (2001) 184:817-26. doi: 10.1086/323346

232. Dhiman N, Ovsyannikova IG, Jacobson RM, Vierkant RA, Pankratz VS, Jacobsen SJ, et al. Correlates of lymphoproliferative responses to measles, mumps, and rubella (MMR) virus vaccines following MMRII vaccination in healthy children. Clin Immunol. (2005) 115:15461. doi: $10.1016 /$ j.clim.2004.12.010

233. Vandermeulen C, Verhoye L, Vaidya S, Clement F, Brown KE, Hoppenbrouwers K, et al. Detection of mumps virus-specific memory B cells by transfer of peripheral blood mononuclear cells into immune-deficient mice. Immunology. (2010) 131:33-9. doi: 10.1111/j.1365-2567.2010.03263.x

234. Nanan R, Heinrich D, Frosch M, Kreth HW. Acute and long-term effects of booster immunisation on frequencies of antigen-specific memory B-lymphocytes. Vaccine. (2001) 20:498-504. doi: 10.1016/S0264-410X(01)00328-0

235. Homan EJ, Bremel RD. Are cases of mumps in vaccinated patients attributable to mismatches in both vaccine T-cell and B-cell epitopes?: an immunoinformatic analysis. Hum Vaccin Immunother. (2014) 10:290300. doi: 10.4161/hv.27139

236. de Wit J, Emmelot ME, Poelen MCM, Lanfermeijer J, Han WGH, van Els $\mathrm{C}$, et al. The human $\mathrm{CD} 4(+) \mathrm{T}$ cell response against mumps virus targets a broadly recognized nucleoprotein epitope. J Virol. (2019) 93:e0188318. doi: 10.1128/JVI.01883-18

237. de Wit J, Emmelot ME, Poelen MCM, van Binnendijk RS, van der Lee S, van Baarle $\mathrm{D}$, et al. Mumps infection but not childhood vaccination induces persistent polyfunctional CD8(+) T-cell memory. J Allergy Clin Immunol. (2018) 141:1908-11.e12. doi: 10.1016/j.jaci.2017.11.047

238. Jokinen S, Osterlund P, Julkunen I, Davidkin I. Cellular immunity to mumps virus in young adults 21 years after measles-mumps-rubella vaccination. $J$ Infect Dis. (2007) 196:861-7. doi: 10.1086/521029

239. Gouma S, Hahne SJ, Gijselaar DB, Koopmans MP, van Binnendijk RS. Severity of mumps disease is related to MMR vaccination status and viral shedding. Vaccine. (2016) 34:1868-73. doi: 10.1016/j.vaccine.2016.02.070

240. Marin M, Quinlisk P, Shimabukuro T, Sawhney C, Brown C, Lebaron CW. Mumps vaccination coverage and vaccine effectiveness in a large outbreak among college students-Iowa, 2006. Vaccine. (2008) 26:36017. doi: 10.1016/j.vaccine.2008.04.075

241. Sane J, Gouma S, Koopmans M, de Melker H, Swaan C, van Binnendijk $\mathrm{R}$, et al. Epidemic of mumps among vaccinated persons, The Netherlands, 2009-2012. Emerg Infect Dis. (2014) 20:643-8. doi: 10.3201/eid2004.131681
242. Zamir CS, Schroeder H, Shoob H, Abramson N, Zentner G. Characteristics of a large mumps outbreak: clinical severity, complications and association with vaccination status of mumps outbreak cases. Hum Vaccin Immunother. (2015) 11:1413-7. doi: 10.1080/21645515.2015.1021522

243. Fanoy EB, Cremer J, Ferreira JA, Dittrich S, van Lier A, Hahne SJ, et al. Transmission of mumps virus from mumps-vaccinated individuals to close contacts. Vaccine. (2011) 29:9551-6. doi: 10.1016/j.vaccine.2011.09.100

244. Polgreen PM, Bohnett LC, Cavanaugh JE, Gingerich SB, Desjardin LE, Harris ML, et al. The duration of mumps virus shedding after the onset of symptoms. Clin Infect Dis. (2008) 46:1447-9. doi: 10.1086/587104

245. Bitsko RH, Cortese MM, Dayan GH, Rota PA, Lowe L, Iversen SC, et al. Detection of RNA of mumps virus during an outbreak in a population with a high level of measles, mumps, and rubella vaccine coverage. J Clin Microbiol. (2008) 46:1101-3. doi: 10.1128/JCM.01803-07

246. Bonwitt J, Kawakami V, Wharton A, Burke RM, Murthy N, Lee A, et al. Notes from the field: absence of asymptomatic mumps virus shedding among vaccinated college students during a mumps outbreak-Washington, February-June 2017. MMWR Morb Mortal Wkly Rep. (2017) 66:13078. doi: 10.15585/mmwr.mm6647a5

247. Kutty PK, Kyaw MH, Dayan GH, Brady MT, Bocchini JA, Reef SE, et al. Guidance for isolation precautions for mumps in the United States: a review of the scientific basis for policy change. Clin Infect Dis. (2010) 50:161928. doi: $10.1086 / 652770$

248. Magurano F, Baggieri M, Marchi A, Bucci P, Rezza G, Nicoletti L. Mumps clinical diagnostic uncertainty. Eur J Public Health. (2018) 28:11923. doi: 10.1093/eurpub/ckx067

249. Gouma S, Sane J, Gijselaar D, Cremer J, Hahne S, Koopmans M, et al. Two major mumps genotype $\mathrm{G}$ variants dominated recent mumps outbreaks in the Netherlands (2009-2012). J Gen Virol. (2014) 95(Pt 5):107482. doi: 10.1099/vir.0.062943-0

250. Andrews N, Pebody RG, Berbers G, Blondeau C, Crovari P, Davidkin I, et al. The European sero-epidemiology network: standardizing the enzyme immunoassay results for measles, mumps and rubella. Epidemiol Infect. (2000) 125:127-41. doi: 10.1017/S0950268899004173

251. Jiskoot W, Kersten GFA, Mastrobattista E, Slütter B. Vaccines. In: Crommelin D, Sindelar R, Meibohm B. editors. Pharmaceutical Biotechnology. Cham: Springer (2019). p. 281-304. doi: 10.1007/978-3-030-00710-2_14

252. Sallusto F, Lanzavecchia A, Araki K, Ahmed R. From vaccines to memory and back. Immunity. (2010) 33:451-63. doi: 10.1016/j.immuni.2010.10.008

253. Thompson KM, Odahowski CL. Systematic review of measles and rubella serology studies. Risk Anal. (2016) 36:1459-86. doi: 10.1111/risa.12430

254. Charlton CL, Lai FY, Dover DC. How to determine protective immunity in the post-vaccine era. Hum Vaccin Immunother. (2016) 12:9036. doi: 10.1080/21645515.2015.1128600

255. Azegami T, Yuki Y, Kiyono $H$. Challenges in mucosal vaccines for the control of infectious diseases. Int Immunol. (2014) 26:517-28. doi: 10.1093/intimm/dxu063

256. Sadoff JC, Wittes J. Correlates, surrogates, and vaccines. J Infect Dis. (2007) 196:1279-81. doi: 10.1086/522432

257. Diaz-Ortega JL, Bennett JV, Castaneda D, Martinez D, Fernandez de Castro J. Aerosolized MMR vaccine: evaluating potential transmission of components to vaccine administrators and contacts of vaccinees. Biologicals. (2012) 40:278-81. doi: 10.1016/j.biologicals.2012.03.002

258. Holmgren J, Svennerholm AM. Vaccines against mucosal infections. Curr Opin Immunol. (2012) 24:343-53. doi: 10.1016/j.coi.2012.03.014

259. Bahamondez-Canas TF, Cui Z. Intranasal immunization with dry powder vaccines. Eur J Pharm Biopharm. (2018) 122:16775. doi: 10.1016/j.ejpb.2017.11.001

260. Holmgren J, Czerkinsky C. Mucosal immunity and vaccines. Nat Med. (2005) 11(Suppl. 4):S45-53. doi: 10.1038/nm1213

261. Rudenko L, van den Bosch H, Kiseleva I, Mironov A, Naikhin A, Larionova $\mathrm{N}$, et al. Live attenuated pandemic influenza vaccine: clinical studies on A/17/California/2009/38 (H1N1) and licensing of the Russian-developed technology to WHO for pandemic influenza preparedness in developing countries. Vaccine. (2011) 29(Suppl. 1):A404. doi: 10.1016/j.vaccine.2011.04.122

262. Carter NJ, Curran MP. Live attenuated influenza vaccine (FluMist(R); Fluenz): a review of its use in the prevention 
of seasonal influenza in children and adults. Drugs. (2011) 71:1591-622. doi: 10.2165/11206860-000000000-00000

263. Galassie AC, Link AJ. Proteomic contributions to our understanding of vaccine and immune responses. Proteomics Clin Appl. (2015) 9:97289. doi: 10.1002/prca.201500054

264. Zhang C, Maruggi G, Shan H, Li J. Advances in mRNA vaccines for infectious diseases. Front Immunol. (2019) 10:594. doi: 10.3389/fimmu.2019.00594

265. Li S, Rouphael N, Duraisingham S, Romero-Steiner S, Presnell S, Davis $\mathrm{C}$, et al. Molecular signatures of antibody responses derived from a systems biology study of five human vaccines. Nat Immunol. (2014) 15:195204. doi: $10.1038 /$ ni.2789

266. Raymond DD, Stewart SM, Lee J, Ferdman J, Bajic G, Do KT, et al. Influenza immunization elicits antibodies specific for an egg-adapted vaccine strain. Nat Med. (2016) 22:1465-9. doi: 10.1038/nm.4223

267. Poland GA. Influenza vaccine failure: failure to protect or failure to understand? Expert Rev Vaccines. (2018) 17:495502. doi: 10.1080/14760584.2018.1484284

268. Amexis G, Rubin S, Chizhikov V, Pelloquin F, Carbone K, Chumakov $\mathrm{K}$. Sequence diversity of Jeryl Lynn strain of mumps virus: quantitative mutant analysis for vaccine quality control. Virology. (2002) 300:1719. doi: 10.1006/viro.2002.1499

269. Zost SJ, Parkhouse K, Gumina ME, Kim K, Diaz Perez S, Wilson PC, et al. Contemporary H3N2 influenza viruses have a glycosylation site that alters binding of antibodies elicited by egg-adapted vaccine strains. Proc Natl Acad Sci USA. (2017) 114:12578-83. doi: 10.1073/pnas.1712377114

270. World Health Organization. Outbreak news: mumps virus vaccines. Wkly Epidemiol Rec. (2007) 7:49-60. Available online at: https://www.who.int/wer/ 2007/wer8207.pdf?ua $=1$

271. Stobart CC, Moore ML. Development of next-generation respiratory virus vaccines through targeted modifications to viral immunomodulatory genes. Expert Rev Vaccines. (2015) 14:1563-72. doi: 10.1586/14760584.2015.1095096

272. Vogel AB, Lambert L, Kinnear E, Busse D, Erbar S, Reuter KC, et al. Self-amplifying RNA vaccines give equivalent protection against influenza to mRNA vaccines but at much lower doses. Mol Ther. (2018) 26:44655. doi: 10.1016/j.ymthe.2017.11.017

273. Xu P, Chen Z, Phan S, Pickar A, He B. Immunogenicity of novel mumps vaccine candidates generated by genetic modification. J Virol. (2014) 88:2600-10. doi: 10.1128/JVI.02778-13

274. Gilchuk P, Hill TM, Wilson JT, Joyce S. Discovering protective CD8 T cell epitopes-no single immunologic property predicts it! Curr Opin Immunol. (2015) 34:43-51. doi: 10.1016/j.coi.2015.01.013

275. Hunt DF, Henderson RA, Shabanowitz J, Sakaguchi K, Michel H, Sevilir $\mathrm{N}$, et al. Characterization of peptides bound to the class I MHC molecule HLA-A2.1 by mass spectrometry. Science. (1992) 255:12613. doi: $10.1126 /$ science. 1546328

276. Zolla-Pazner S. Identifying epitopes of HIV-1 that induce protective antibodies. Nat Rev Immunol. (2004) 4:199-210. doi: 10.1038/nri1307

277. Jansen VA, Altes HK, Funk GA, Wodarz D. Contrasting B celland $\mathrm{T}$ cell-based protective vaccines. I Theor Biol. (2005) 234:3948. doi: 10.1016/j.jtbi.2004.11.006

278. Bahl K, Senn JJ, Yuzhakov O, Bulychev A, Brito LA, Hassett KJ, et al. Preclinical and clinical demonstration of immunogenicity by mRNA vaccines against H10N8 and H7N9 influenza viruses. Mol Ther. (2017) 25:1316-27. doi: 10.1016/j.ymthe.2017.03.035

279. ClinicalTrials.gov. Safety and Immunogenicity Study of 2019-nCoV Vaccine (mRNA-1273) for Prophylaxis of SARS-CoV-2 Infection (COVID-19). (2020) Available online at: https://clinicaltrials.gov/ct2/show/NCT04283461 (accessed May 11, 2020).

280. Pijlman GP, Suhrbier A, Khromykh AA. Kunjin virus replicons: an RNAbased, non-cytopathic viral vector system for protein production, vaccine and gene therapy applications. Expert Opin Biol Ther. (2006) 6:13545. doi: $10.1517 / 14712598.6 .2 .135$

281. Lundstrom K. RNA Viruses as tools in gene therapy and vaccine development. Genes. (2019) 10:1-24. doi: 10.3390/genes10030189

282. Poland GA, Whitaker JA, Poland CM, Ovsyannikova IG, Kennedy RB. Vaccinology in the third millennium: scientific and social challenges. Curr Opin Virol. (2016) 17:116-25. doi: 10.1016/j.coviro.2016.03.003
283. Ovsyannikova IG, Poland GA. Vaccinomics: current findings, challenges and novel approaches for vaccine development. AAPS J. (2011) 13:43844. doi: 10.1208/s12248-011-9281-x

284. Delany I, Rappuoli R, De Gregorio E. Vaccines for the 21st century. EMBO Mol Med. (2014) 6:708-20. doi: 10.1002/emmm.201403876

285. Pezeshki A, Ovsyannikova IG, McKinney BA, Poland GA, Kennedy RB. The role of systems biology approaches in determining molecular signatures for the development of more effective vaccines. Expert Rev Vaccines. (2019) 18:253-67. doi: 10.1080/14760584.2019.1575208

286. Durando P, Iudici R, Alicino C, Alberti M, de Florentis D, Ansaldi F, et al. Adjuvants and alternative routes of administration towards the development of the ideal influenza vaccine. Hum Vaccin. (2011) 7:2940. doi: 10.4161/hv.7.0.14560

287. Sanchez-Ramon S, Conejero L, Netea MG, Sancho D, Palomares O, Subiza JL. Trained immunity-based vaccines: a new paradigm for the development of broad-spectrum anti-infectious formulations. Front Immunol. (2018) 9:2936. doi: 10.3389/fimmu.2018.02936

288. Fidel PL, Noverr MC. Could an unrelated live attenuated vaccine serve as a preventive measure to dampen septic inflammation associated with COVID19 infection? mBio. (2020) 11:e00907-20. doi: 10.1128/mBio.00907-20

289. Schalk JA, de Vries CG, Jongen PM. Potency estimation of measles, mumps and rubella trivalent vaccines with quantitative PCR infectivity assay. Biologicals. (2005) 33:71-9. doi: 10.1016/j.biologicals.2005.01.001

290. European Medicines Agency. Evaluation of Medicines for Human Use. (2006). Avaiable online at: https://www.ema.europa.eu/en/documents/ scientific-discussion/m-m-rvaxpro-epar-scientific-discussion_en.pdf (accessed January 7, 2020).

291. European Medicines Agency. Quality of Biotechnological Products: Viral Safety Evaluation of Biotechnology Products from Cell Lines of Human or Animal Origin. Step 5. (2008). Available online at: https://www.ema.europa. eu/en/documents/scientific-guideline/ich-q-5-r1-viral-safety-evaluationbiotechnology-products-derived-cell-lines-human-animal-origin_en.pdf (accessed May 11, 2020).

292. Crowcroft NS, Klein NP. A framework for research on vaccine effectiveness. Vaccine. (2018) 36:7286-93. doi: 10.1016/j.vaccine.2018. 04.016

293. Brown EG, Dimock K, Wright KE. The Urabe AM9 mumps vaccine is a mixture of viruses differing at amino acid 335 of the hemagglutininneuraminidase gene with one form associated with disease. J Infect Dis. (1996) 174:619-22. doi: 10.1093/infdis/174.3.619

294. Yamanishi K, Takahashi M, Ueda S, Minekawa Y, Ogino T. Studies on live mumps virus vaccine. V. Development of a new mumps vaccine "AM 9" by plaque cloning. Biken J. (1973) 16:161-6.

295. Boesch AW, Brown EP, Cheng HD, Ofori MO, Normandin E, Nigrovic PA, et al. Highly parallel characterization of IgG Fc binding interactions. MAbs. (2014) 6:915-27. doi: 10.4161/mabs.28808

296. Heininger U, Bachtiar NS, Bahri P, Dana A, Dodoo A, Gidudu J, et al. The concept of vaccination failure. Vaccine. (2012) 30:12658. doi: 10.1016/j.vaccine.2011.12.048

297. Nyhan B, Reifler J, Richey S, Freed GL. Effective messages in vaccine promotion: a randomized trial. Pediatrics. (2014) 133:e835-42. doi: 10.1542/peds.2013-2365

298. Hoffman BL, Felter EM, Chu KH, Shensa A, Hermann C, Wolynn T, et al. It's not all about autism: the emerging landscape of anti-vaccination sentiment on Facebook. Vaccine. (2019) 37:2216-23. doi: 10.1016/j.vaccine.2019. 03.003

Conflict of Interest: The authors declare that the research was conducted in the absence of any commercial or financial relationships that could be construed as a potential conflict of interest.

Copyright $\odot 2020$ Connell, Connell, Leahy and Hassan. This is an open-access article distributed under the terms of the Creative Commons Attribution License (CC BY). The use, distribution or reproduction in other forums is permitted, provided the original author(s) and the copyright owner(s) are credited and that the original publication in this journal is cited, in accordance with accepted academic practice. No use, distribution or reproduction is permitted which does not comply with these terms. 